\title{
The Interaction between Arbuscular Mycorrhizal Fungi and Endophytic Bacteria Enhances Plant Growth of Acacia gerrardii under Salt Stress
}

\author{
Abeer Hashem ${ }^{1,2}$, Elsayed F. Abd_Allah ${ }^{3 *}$, Abdulaziz A. Alqarawi ${ }^{3}$, Asma A. Al-Huqail ${ }^{1}$, \\ Stephan Wirth ${ }^{4}$ and Dilfuza Egamberdieva ${ }^{4}$ \\ ${ }^{1}$ Department of Botany and Microbiology, Faculty of Science, King Saud University, Riyadh, Saudi Arabia, ${ }^{2}$ Department of \\ Mycology and Plant Disease Survey, Agriculture Research Center, Plant Pathology Research Institute, Giza, Egypt, \\ ${ }^{3}$ Department of Plant Production, Faculty of Food and Agricultural Sciences, King Saud University, Riyadh, Saudi Arabia, \\ ${ }^{4}$ Leibniz Centre for Agricultural Landscape Research, Institute of Landscape Biogeochemistry, Müncheberg, Germany
}

\section{OPEN ACCESS}

Edited by:

Kumar Krishnamurthy,

Tamil Nadu Agricultural University,

India

Reviewed by:

Biswapriya Biswavas Misra

University of Florida, USA

Joseph Davis Bagyaraj,

Indian National Science Academy,

India

*Correspondence:

Elsayed F. Abd_Allah

eabdallah@ksu.edu.sa

Specialty section:

This article was submitted to

Plant Biotic Interactions,

a section of the journal

Frontiers in Microbiology

Received: 17 February 2016

Accepted: 29 June 2016

Published: 19 July 2016

Citation:

Hashem A, Abd Allah EF

Alqarawi AA, Al-Huqail AA, Wirth S and Egamberdieva $D$ (2016) The

Interaction between Arbuscular

Mycorrhizal Fungi and Endophytic Bacteria Enhances Plant Growth of Acacia gerrardii under Salt Stress.

Front. Microbiol. 7:1089.

doi: 10.3389/fmicb.2016.01089
Microbes living symbiotically in plant tissues mutually cooperate with each other by providing nutrients for proliferation of the partner organism and have a beneficial effect on plant growth. However, few studies thus far have examined the interactive effect of endophytic bacteria and arbuscular mycorrhizal fungi (AMF) in hostile conditions and their potential to improve plant stress tolerance. In this study, we investigated how the synergistic interactions of endophytic bacteria and AMF affect plant growth, nodulation, nutrient acquisition and stress tolerance of Acacia gerrardii under salt stress. Plant growth varied between the treatments with both single inoculants and was higher in plants inoculated with the endophytic $B$. subtilis strain than with AMF. Co-inoculated A. gerrardii had a significantly greater shoot and root dry weight, nodule number, and leghemoglobin content than those inoculated with AMF or B. subtilis alone under salt stress. The endophytic $B$. subtilis could alleviate the adverse effect of salt on AMF colonization. The differences in nitrate and nitrite reductase and nitrogenase activities between uninoculated plants and those inoculated with AMF and B. subtilis together under stress were significant. Both inoculation treatments, either $B$. subtilis alone or combined with AMF, enhanced the N, P, K, Mg, and Ca contents and phosphatase activities in salt-stressed $A$. gerrardii tissues and reduced $\mathrm{Na}$ and $\mathrm{Cl}$ concentration, thereby protecting salt-stressed plants from ionic and osmotic stress-induced changes. In conclusion, our results indicate that endophytic bacteria and AMF contribute to a tripartite mutualistic symbiosis in A. gerrardii and are coordinately involved in the plant adaptation to salt stress tolerance.

Keywords: AMF, endophyte, Acacia gerrardii, salinity, nutrition

\section{INTRODUCTION}

Salinity is a devastating environmental stress factor that severely affects plant growth and development (Barnawal et al., 2014). At the global level, particularly in arid and semiarid regions, salinity is considered an important constraint, and approximately $7 \%$ of global land has a high salt concentration, making this area unavailable for agriculture (Sheng et al., 2008; Ruiz-Lozano et al., 2012). Salinity reduces plant growth through osmotic as well as ionic constraints of major 
physiological and biochemical processes (Ahmad, 2010; Porcel et al., 2012; Abd_Allah et al., 2015a). This may in turn alter the availability of nutrients for plant growth and affect the association with microbes living within the plant vicinity. Plants are colonized by microbes, including endophytes, nitrogen-fixing bacteria and mycorrhizal fungi, which closely cooperate with each other and can mediate important physiological processes, especially nutrient acquisition and plant tolerance to abiotic stresses (Egamberdieva, 2012; Egamberdieva et al., 2013, 2015; Berg et al., 2013; Ahanger et al., 2014a; Abd_Allah et al., 2015a). Arbuscular mycorrhiza fungi (AMF) form beneficial symbiotic associations with most plants and play a vital role in plant growth under various conditions by modifying the root system and enhancing mobilization and the uptake of several essential elements. They have also been reported to stimulate plant stress tolerance by enhancing enzymatic as well as nonenzymatic antioxidant defense systems (Wu et al., 2014; Ahmad et al., 2015), lipid peroxidation (Abd_Allah et al., 2015c), and phytohormone synthesis (Navarro et al., 2013). Endophytic bacteria colonize the internal tissues of their host plants and can promote growth, stress tolerance, and nutrient uptake and protect plants from soil-borne pathogens (Malfanova et al., 2011; Sessitsch et al., 2012). Microbes living symbiotically in plant tissues, such as mycorrhizal fungi, and nitrogen-fixing bacteria also mutually cooperate with each other by synthesizing biologically active compounds and providing nutrients for the survival and proliferation of their partner organism (Marschner et al., 2001; Egamberdieva et al., 2013). These synergies among endophytes are known to have beneficial effects on plants by improving the availability of nutrients to plants and inducing plant defense against various stresses, including drought and salinity.

The symbiotic relationship between legumes and nitrogenfixing rhizobia is susceptible to abiotic factors, such as nutrient deficiency, salinity, drought, acidity, and soil temperature, which induce failure of the infection and nodulation processes (Slattery et al., 2001; Bouhmouch et al., 2005; Egamberdieva et al., 2013). An improvement in legume-rhizobia symbiotic performance by AMF has been reported for faba bean (Vicia faba) (Yinsuo et al., 2004), lucerne (Medicago sativa) (Ardakani et al., 2009), lentil (Lens culinaris) (Xavier and Germida, 2002), and common bean (Phaseolus vulgaris) (Tajini et al., 2012). The positive effects on plant growth and stimulation of stress tolerance by synergistic interactions of root-colonizing, plant growth-promoting bacteria (PGPR) and AMF under hostile environments have been extensively reviewed by Nadeem et al. (2014). These microbes are believed to act as essential bio-ameliorators of stress by regulating the nutritional and hormonal balance (Abd_Allah et al., 2015a,b; Egamberdieva et al., 2015, 2016) and inducing systemic tolerance to stress (Ruiz-Lozano et al., 2012).

Despite these beneficial associations of microbes, studies examining the interactions of endophytic bacteria and AMF in hostile environmental conditions are limited, especially where competition for nutrient and niches in the rhizosphere is high. This knowledge is important for our understanding of the relationship between AMF and endophytic bacteria and their potential effect on plant stress tolerance and for the development of crop management practices under hostile environmental conditions.

Acacia gerrardii Benth. (Talh tree) is a small leguminous shrub that is resistant to drought and salinity, forms nodules and can improve the fertility of salt-affected arid soils. This tree is widely used in Saudi Arabia for fuel, forage, medicine, food production and also for agroforestry. In this study, we hypothesize that the improved salt tolerance and growth of $A$. gerrardii are mediated by (i) the effect of endophytic bacteria on mycorrhizal development and colonization in the roots of $A$. gerrardii and (ii) nodulation, nutrient acquisition by a synergistic interaction between endophytic bacteria and AMF.

\section{MATERIALS AND METHODS}

\section{Plants and Microorganisms} Isolation of Endophytic Bacteria

Roots of Talh trees were collected from the top $20 \mathrm{~cm}$ of soil in a natural meadow at Khuraim in Riyadh, Saudi Arabia. The samples were wrapped in a plastic bag and brought to the laboratory, where they were incubated at $4^{\circ} \mathrm{C}$ until further processing. One gram of roots was surface-sterilized by immersion in $70 \%$ ethanol, followed by $5 \%$ sodium hypochlorite for $5 \mathrm{~min}$, and then rinsed in sterile distilled water four to six times to eliminate the chlorine. The sterilized roots were macerated, and the extracts were placed in a tube containing 9 $\mathrm{ml}$ of sterile phosphate-buffered saline and then serially diluted. A $100 \mu \mathrm{l}$ aliquot from the appropriate dilutions was plated on tryptic soy agar (TSA, Difco Laboratories, Detroit, USA) supplemented with $4 \% \mathrm{NaCl}$. The plates were incubated at $28^{\circ} \mathrm{C}$ for 3 days, and all colonies that displayed differentiable colony morphologies were selected from the plates and were re-streaked to purify the strains. To select strains with increased stress tolerance, the purified isolates were cultured in TSA medium supplemented with 3,4 , or $5 \%$ (w/v) $\mathrm{NaCl}$.

\section{Identification of the Selected Strain}

A highly salt-tolerant strain, which grew well in TSA medium containing $4 \% \mathrm{NaCl}$, was identified. DNA was isolated by a modified version of the Töpper et al. (2010) protocol. The filters were re-suspended in $250 \mu$ l of lysozyme solution ( $1 \mathrm{mg}$ $\mathrm{ml}^{-1}$ TE buffer, $\left.\mathrm{pH} 7.4\right)$. Then, $250 \mu \mathrm{l}$ of preheated $\left(55^{\circ} \mathrm{C}\right)$ lysis buffer (20 $\mu \mathrm{g}$ proteinase $\mathrm{K} \mathrm{ml}^{-1} 0.5 \%$ SDS) was added to the solution. After incubation for $30 \mathrm{~min}$ at $55^{\circ} \mathrm{C}, 80 \mu \mathrm{l}$ of $5 \mathrm{M} \mathrm{NaCl}$ and $100 \mu \mathrm{l}$ of preheated $\left(55^{\circ} \mathrm{C}\right) \mathrm{CTAB}[10 \%$ $(\mathrm{w} / \mathrm{v})$ hexadecyltrimethylammonium bromide in $0.7 \% \mathrm{NaCl}$ ] were added. The solution was incubated for a further 10 $\min$ at $65^{\circ} \mathrm{C}$ followed by the addition of $500 \mu \mathrm{l}$ chloroform: isoamylalcohol $(24: 1, \mathrm{v} / \mathrm{v})$. The solution was centrifuged $(16,000$ $\times \mathrm{g}, 5 \mathrm{~min})$ to separate the DNA from the remaining cell debris. Then, the top phase was transferred to a fresh tube, and the DNA was precipitated with isopropanol and later resuspended in TE buffer ( $\mathrm{pH}$ 7.4). Next, 16S rDNA was amplified by polymerase chain reaction (PCR) using universal forward 16SF (5'-GAGTTTGATCCTGGCTCAG-3') and reverse 16SR (5'-GAAAGGAGGTGATCCAGCC-3') primers (Mohanta et al., 2015). The PCR reactions were $25 \mu \mathrm{l}$ and contained $5 \mu \mathrm{l}$ of 
$5 \times$ buffer (TaKaRa Bio Inc.), $0.5 \mu$ l of dNTP mixture $(10 \mathrm{mM}$ of each dNTP, TaKaRa Bio Inc.), $1 \mu$ l of $2 \%$ BSA (Promega), 0.5 $\mu l$ of forward primer $(10 \mu \mathrm{M}), 0.5 \mu \mathrm{l}$ of reverse primer $(10 \mu \mathrm{M})$, $0.125 \mu \mathrm{l}$ of One Taq DNA Polymerase (New England Biolabs), 15.375 MQ and $2 \mu \mathrm{l}$ of template DNA. The PCR program (BioRad DNA Engine) started with an initial denaturation step for $30 \mathrm{~s}$ at $94^{\circ} \mathrm{C}$ followed by 30 cycles of $15 \mathrm{~s}$ at $94^{\circ} \mathrm{C}, 30 \mathrm{~s}$ at $55^{\circ} \mathrm{C}$ and $1.5 \mathrm{~min}$ at $68^{\circ} \mathrm{C}$. Before cooling to $4^{\circ} \mathrm{C}$, an extension period of $20 \mathrm{~min}$ at $68^{\circ} \mathrm{C}$ was incorporated into the program. The PCR products were verified by gel electrophoresis on a $1.5 \%$ agarose gel stained with TAE (Tris-acetate-EDTA). Denaturing gradient gel electrophoresis (DGGE) was performed using the DCode system (Bio-Rad). Equal amounts of PCR products (6 $\mu \mathrm{l})$ were loaded onto $8 \%$ acrylamide gels with a denaturing gradient of $30-55 \%$ [where $100 \%$ denaturing is defined as 7 $\mathrm{M}$ urea and 40\% (v/v) formamide (Muyzer et al., 1995)] for optimal separation of the PCR products. DGGE gels were run for $19 \mathrm{~h}$ at $60 \mathrm{~V}$ and at $60^{\circ} \mathrm{C}$ in 0.59 TAE buffer and stained for 30 min with SYBR Gold (Invitrogen) diluted 10,000-fold in $19 \times$ TAE buffer. Gels were visualized and digitized using the Fujifilm Imaging System. The PCR product was purified, and nucleotide sequences were determined using automatic LI-COR DNA Sequencer 4000 L (Lincoln, USA). The sequences were identified using the basic local alignment search tool (BLAST) and comparisons with the GenBank nucleotide data bank from the National Center for Biotechnology Information (NCBI) (http://www.ncbi.nlm.nih.gov/).

\section{Plant Growth-Promoting Traits}

The cellulose-degrading ability of bacterial isolates was analyzed by streaking inocula on cellulose Congo Red agar media, as described by Gupta et al. (2012). Zones of clearance around and beneath the colony were detected, indicating enzymatic degradation of cellulose.

The production of indole 3-acetic acid (IAA) was determined as described by Bano and Musarrat (2003). Briefly, bacterial strains were grown in TSB medium. After 3 days, $1 \mathrm{ml}$ of each culture was pelleted by centrifugation, and the supernatant was discarded. Cell pellets were washed with $1 \mathrm{ml}$ of PBS and re-suspended in PBS. One milliliter of cell suspension (corresponding to a cell density of $10^{7}$ cells $/ \mathrm{ml}$ ) was added to $10 \mathrm{ml}$ of TSB supplemented with tryptophan $(100 \mu \mathrm{g} / \mathrm{ml})$. After 3 days of cultivation, $2 \mathrm{ml}$ aliquots of bacterial cultures were centrifuged at $13,000 \times \mathrm{g}$ for $10 \mathrm{~min}$. One milliliter of supernatant was transferred to a fresh tube to which $100 \mu \mathrm{g} / \mathrm{ml}$ of $10 \mathrm{mM}$ orthophosphoric acid and $2 \mathrm{ml}$ of reagent $(1 \mathrm{ml}$ of $0.5 \mathrm{M} \mathrm{FeCl}_{3}$ in $50 \mathrm{ml}$ of $35 \% \mathrm{HClO}_{4}$ ) were added. After $25 \mathrm{~min}$, the absorbance of the sample was measured at $530 \mathrm{~nm}$. The IAA concentration in cultures was calculated using a calibration curve of pure IAA as the standard.

The phosphate-solubilizing activity of the bacterial strains was determined on Pikovskaya agar (Pikovskaya, 1948) containing precipitated tricalcium phosphate. The bacterial culture grown in TSA medium for 2 days was streaked on the surface of Pikovskaya agar plates and incubated for 3 days. The presence of a clear zone around bacterial colonies was considered to be an indicator of positive $\mathrm{P}$ solubilization.

\section{Arbuscular Mycorrhizal Fungi}

AMF were isolated from the soil surrounding the roots of A. gerrardii. AMF were extracted by wet sieving, decanting and sucrose density gradient centrifugation as described by Daniels and Skipper (1982) and modified by Utobo et al. (2011). Briefly, $100 \mathrm{~g}$ of soil was placed in a $10 \mathrm{~L}$ bucket, and $5 \mathrm{~L}$ of tap water was added to the soil and mixed well to produce a soil-water suspension. The suspension was left for $5 \mathrm{~min}$ to allow insoluble and heavy particles to settle, and the suspension was sequentially sieved through ASTM500, ASTM-250, ASTM-150, and ASTM-50 sieves to extract the spores using a wet sieving and decanting method (Gerdemann and Nicolson, 1963). The sieved residues were filtered through Whatman filter paper No. 1. After water filtration, the filter paper was examined under a stereo-binocular microscope at 25 $\times$ magnification. Morphologically similar spores were selected for identification. AMF species were identified based on the description of subcellular structures (spore color, shape, surface ornamentation, spore contents, and wall structures) of asexual spores provided by the International Culture Collection of Vesicular and Arbuscular Mycorrhizal Fungi (INVAM 2012) ${ }^{1}$ and other descriptive protocols (Bethlenfalvay and Yoder, 1981; Schüßler and Walker, 2010; Redecker et al., 2013).

\section{Propagation of AMF in Trap Cultures}

The trap culture protocol described by Stutz and Morton (1996) was used in the current study to propagate the most efficient mycorrhizal isolates. Sterilized sand $\left(121^{\circ} \mathrm{C}\right.$ for 3 days $)$ was inoculated with single spores from each mycorrhizal isolate. Surface-sterilized seeds [0.5\% (v/v) $\mathrm{NaOCl}$ used] of Sorghum sudanense were sown (20 seeds/pot) at a depth of $2 \mathrm{~cm}$ in each pot $(5 \mathrm{~kg}$ capacity) of trap cultures. The pots were incubated in a plant growth chamber at $25 \pm 2^{\circ} \mathrm{C}$ with $18 \mathrm{~h}$ photoperiod, $750 \mu \mathrm{mol} \mathrm{m} \mathrm{m}^{-2} \mathrm{~s}^{-1}$ photosynthetic photon flux density, and $70-75 \%$ relative humidity for 3 months. Half-strength Hoagland's solution was used to irrigate the pots. The trap culture was used as the mycorrhizal inoculum and was added to the experimental soil as $25 \mathrm{~g}$ of trap soil culture (approx. 100 spores/g trap soil)/pot. Soil not inoculated with mycorrhiza served as the control.

\section{Determination of Arbuscular Mycorrhizal Colonization}

At the end of the pot experiment (12 weeks), fine roots were collected from the lateral root system and fixed in formalin/acetic acid/alcohol (v/v/v) (FAA) solution until further processing. Roots were stained with trypan blue in lactophenol (Phillips and Hayman, 1970) and assessed for mycorrhizal infection. Roots that were pigmented after clearing were bleached in alkaline hydrogen peroxide $\left(0.5 \% \mathrm{NH}_{4} \mathrm{OH}\right.$ and $0.5 \% \mathrm{H}_{2} \mathrm{O}_{2} \mathrm{v} / \mathrm{v}$ in water) to remove any phenolic compounds (Kormanik and McGraw, 1982) before acidification $(0.05 \mathrm{M} \mathrm{HCl})$. To assess mycorrhizal colonization, stained root segments (one $\mathrm{cm}$ in length) were mounted on glass slides with lactophenol and were observed under a digital computerized microscope (model DP-72, Olympus) at $20 \times$

${ }^{1}$ INVAM - International Culture Collection of Arbuscular \& Vesicular-Arbuscular Mycorrhizal Fungi. Available online at: www.invam.caf.wvu.edu/index.html (Accessed February 6, 2012). 
magnification. A minimum of 50 segments for each replicate sample were observed to assess structural colonization of AMF associated with roots. Twenty or more segments were mounted on each slide and examined under the microscope. The presence of mycelia, vesicles and arbuscules was recorded and analyzed to assess structural colonization.

\section{Germination of Seeds}

Acacia gerrardii seeds were surface-sterilized by immersion for $5 \mathrm{~min}$ in concentrated sulfuric acid followed by $3 \mathrm{~min}$ in $70 \%$ ethanol and were rinsed five times with sterile, distilled water.

Germination tests were carried out in Petri dishes $(\varnothing$ $85 \times 15 \mathrm{~mm}$ ) containing $1 \%$ water agar. Salinity conditions were established by adding 50, 100, 150, 200, 250, and $300 \mathrm{mM}$ $\mathrm{NaCl}$. Twenty healthy and surface-sterilized seeds were placed on each Petri dish and were arranged in a randomized complete block design with three replications. Eventually, the Petri dishes were covered with a polyethylene sheet to avoid the loss of the moisture through evaporation and kept in the plant growth chamber at $28^{\circ} \mathrm{C}$. The seeds were observed daily, and the percent germination was recorded after 10 days of incubation. Seeds were considered to have germinated when the emerging radicles were greater than $0.5 \mathrm{~cm}$ long.

\section{Plant Growth Condition}

This experiment was carried out in the growth chamber of the Plant Production Department, Faculty of Food \& Agricultural Sciences, King Saud University, Riyadh, Saudi Arabia. Talh tree seeds were provided by a personal nursery in Alghat, Riyadh that produces tree seedlings. The soil used was loamy sand soil with the following properties (\%): sand (87.6), clay (7.2), silt (5.2), organic carbon (0.12), total nitrogen (0.005), $\mathrm{pH} 7.5$. The sand was washed with $1.0 \mathrm{~N} \mathrm{H}_{2} \mathrm{SO}_{4}$ for $1 \mathrm{~h}$, followed by $1.0 \mathrm{~N}$ $\mathrm{Ca}$ carbonate, and was then washed using distilled water. The surface-sterilized seeds were sown in acid-washed sterile sand and kept in a plant growth chamber under the same conditions described for trap cultures for 1 month.

The bacterial strain was grown in TSB medium for 2 days, and $1 \mathrm{ml}$ of culture suspension was pelleted by centrifugation. The supernatant was discarded, and the cell pellets were washed with $1 \mathrm{ml}$ phosphate-buffered saline and diluted to a cell density of $10^{8}$ cells/ml. Roots of 1-month-old seedlings were immersed in the bacterial suspension for $30 \mathrm{~min}$ and sown in pots (1 seedling per pot) filled with $2 \mathrm{~kg}$ of sandy loam soil mixed with mycorrhizal inoculum [i.e., $25 \mathrm{~g}$ of trap soil culture or approx. 100 spores/g trap soil $(M=80 \%) /$ pot]. The experiment was a completely randomized design with five replicates for each treatment: (i) Control without microbes, (ii) Bacillus subtilis (BS), (iii) AMF, and (iv) B. subtilis combined with AMF (BS+AMF). Plants were grown in a greenhouse for 12 weeks with average day/night temperatures of $25^{\circ} \mathrm{C} / 18^{\circ} \mathrm{C}$ and were supplemented with tap water as required. Salinity was established by adding $\mathrm{NaCl}$ to the irrigation solution to obtain a constant concentration of 250 $\mathrm{mM}$. At harvest, plants were harvested carefully, and shoots were separated from roots and dried to constant weight at $100^{\circ} \mathrm{C}$. Fresh nodules were used to estimate leghemoglobin (LB) levels as well as the activities of nitrite reductase, nitrate reductase, and nitrogenase. Fresh leaf samples were used to assess the content of photosynthetic pigments.

\section{Nodulation, Leghemoglobin, and Crude Protein Contents}

The nodule fresh weight (FW) and the number of nodules per plant root were determined. The leghemoglobin concentration of root nodules was estimated using the method of Keilin and Wang (1945). Fresh nodules (2.0 g) were ground to a fine powder in liquid $\mathrm{N}_{2}$ and transferred to $50 \mathrm{mM} \mathrm{KPO}_{4}(\mathrm{pH}$ 7.4) buffer containing $1 \mathrm{mM}$ EDTA. The mixture was stirred until it thawed into a homogenate at a final temperature of $2^{\circ} \mathrm{C}$, transferred to centrifuge tubes and centrifuged at $4^{\circ} \mathrm{C}$ and $10,000 \times \mathrm{g}$ for $10 \mathrm{~min}$. The leghemoglobin-containing supernatant was collected and maintained at a known volume with $50 \mathrm{mM}$ $\mathrm{KPO}_{4}$ (pH 7.4) buffer as described above. The color intensity that developed was recorded spectrophotometrically at $710 \mathrm{~nm}$ against a blank, which contained $50 \mathrm{mM} \mathrm{KPO}_{4}(\mathrm{pH}$ 7.4) buffer with $1 \mathrm{mM}$ EDTA. Leghemoglobin concentration was expressed as $\mathrm{mg} / \mathrm{g}$ nodule (FW). The micro-Kjeldahl method described by Allen (1953) was used to estimate the total nitrogen content of oven-dried $\left(110^{\circ} \mathrm{C}\right.$ for two successive weights) nodules. Crude protein concentration $(\%, \mathrm{w} / \mathrm{w})$ was determined mathematically by multiplying total nitrogen content by the general factor for cereal protein determination, 6.25, as described in the AOAC Official Method 992.23 (AOAC Association of Official Analytical Chemists, 1995).

\section{Nitrate and Nitrite Reductase and Nitrogenase Activity}

Nitrate and nitrite reductase activities in the nodules were assayed using the methods of Hageman and Hucklesby (1971) and Finka et al. (1977), respectively. Phosphate buffer $(\mathrm{pH}$ 7.5) containing $0.1 \mathrm{M}$ potassium nitrate and 5\% n-propanol was used to extract the reductases. The optical density of the samples was measured spectrophotometrically at $550 \mathrm{~nm}$. A standard curve of potassium nitrite was used as a reference. The activity of nitrate and nitrite reductases was expressed as $\mu \mathrm{mNO}_{2}$ released/h/g FW and $\mu \mathrm{mNO}_{2}$ disappeared/h/g fresh wt, respectively. Nitrogenase (EC 1.7.99.2) activity (ARA) was determined by acetylene reduction with the known weight of the nodules collected from all nodulated root portions of the plants, following the method of Herdina and Silsbury (1990). Gas samples were analyzed for ethylene produced in the reaction using a Shimadzu GC-14B gas chromatograph equipped with a Porapak R column (Ligero et al., 1986).

\section{Determination of Photosynthetic Pigments}

Photosynthetic pigments were extracted from leaf samples in $80 \%$ acetone as described by Arnon (1949). Fresh leaf samples (0.5 g) were extracted in $80 \%$ acetone $(\mathrm{v} / \mathrm{v})$. The extracted material was centrifuged at $10,000 \times \mathrm{g}$ for $10 \mathrm{~min}$. The optical density of the supernatants was recorded at 480,645, and $663 \mathrm{~nm}$ using a UV-visible spectrophotometer (T80 UV/VIS spectrometer, PG Instruments Ltd., USA). A blank with $80 \%$ acetone served as the control. 


\section{Estimation of Acid and Alkaline Phosphatase Activity}

Fresh root samples were extracted with $0.1 \mathrm{M}$ acetate buffer ( $\mathrm{pH}$ 5.0) and 0.1 M Tris HCI buffer ( $\mathrm{pH}$ 8.2) for acid phosphatase (AP) (EC 3.1.3.2) and alkaline phosphatase (ALP) (EC 3.1.3.1), respectively, as described by Gianinazzi-Pearson and Gianinazzi (1976). AP and ALP were assayed following the methods of Ikawa et al. (1964) and Torriani (1967), respectively. In these methods, the reaction mixture of AP contained $0.2 \mathrm{ml}$ of enzyme extract and $1.0 \mathrm{ml}$ of $5.5 \mathrm{mM}$-nitrophenol phosphate in $5.5 \mathrm{mM}$ citrate buffer ( $\mathrm{pH} 4.8$ ). For the ALP assays, 0.05 M Tris-citrate ( $\mathrm{pH}$ 8.5) was used instead of citrate buffer $\left(\mathrm{pH}\right.$ 4.8). The reaction mixtures were incubated at $37^{\circ} \mathrm{C}$ for $30 \mathrm{~min}$, and the reactions were stopped by adding $10 \mathrm{ml}$ of $200 \mathrm{mM} \mathrm{NaOH}$. Absorbance was recorded at $410 \mathrm{~nm}$, and activity was expressed as $\mu \mathrm{mol} p$-nitrophenol released $\mathrm{min} / \mathrm{mg}$ protein.

\section{Determination of Mineral Contents}

To determine the mineral contents, oven-dried leaves were powdered, and the powder was digested with $98 \% \mathrm{H}_{2} \mathrm{SO}_{4}$ and $30 \% \quad \mathrm{H}_{2} \mathrm{O}_{2}$. The total nitrogen $(\mathrm{N})$ content in leaf tissues was determined following the semi-micro Kjedahl procedure using a nitrogen analyzer (Kjedahl 2300; FOSS, Hoganas, Sweden). The phosphorus (P) content was estimated using the vanadomolybdophosphoric colorimetric method (Jackson, 1962). A standard curve (10-100 $\mu \mathrm{g} / \mathrm{ml})$ of potassium dihydrogen phosphate $\left(\mathrm{KH}_{2} \mathrm{PO}_{4}\right)$ was used as the reference. The contents of $\mathrm{Na}^{+}, \mathrm{K}^{+}, \mathrm{Mg}^{2+}$, and $\mathrm{Ca}^{2+}$ in plant leaves were estimated as described by Wolf (1982) using a flame photometer (Jenway Flame Photometer, Bibby Scientific Ltd., Stone-Staffs, $\mathrm{UK})$. The chloride $\left(\mathrm{Cl}^{-}\right)$concentration was directly estimated in the digested extracts using a chloride analyzer (Model 926, Sherwood Scientific Ltd., Cambridge, UK), as described by Abd_Allah et al. (2015b).

\section{Statistical Analyses}

Duncan's multiple range test was performed using one-way analysis of variance (ANOVA) for a completely randomized design by SPSS-21 software, and significant differences in means were determined by the least significant differences (LSD) ( $p=$ 0.05 ) test. In addition, the correlation coefficients among the parameters studied were calculated and are presented in Tables 3, 5, Table S3.

\section{RESULTS}

\section{Identification of Microorganisms}

Using nucleotide homology and phylogenetic analysis of the $16 \mathrm{~S}$ rRNA gene sequences, we grouped the microbe that showed the highest salt tolerance in a cluster containing B. subtilis (GenBank Accession Number: JX188065.1) with 99\% sequence similarity. The genome sequence of $B$. subtilis BERA71 was deposited in GenBank with the accession number KX090253. The strain produced IAA in nutrient broth containing $1.5 \%(260 \mathrm{mM})$ $\mathrm{NaCl}$ and cellulose and also solubilized mineral phosphorus from tricalcium phosphate used in solid medium.
Photomicrographs in (Figures 1A-F) showing spore morphology of AMF (Claroideoglomus etunicatum, Rhizophagus intraradices, Funneliformis mosseae) used in the current study. Figures 1A,B Crushed spore of C. etunicatum showing depressions on the surface and two wall layers: L1, an outer permanent rigid layer with some plasticity and an uneven outer surface. L2, A layer consisting of laminae that increase in thickness ( $\sim 8.0 \mu \mathrm{m}$ thick) is rigid, exhibiting some swelling and spreading when broken. $R$. intraradices: Figures 1C,D Crushed yellow-brown spore, globose or subglobose in shape, consists of three layers. L1, Outer layer has a sloughing spore wall (SSW), hyaline, mucilaginous spores that stain pale pink. L2: A rigid hyaline layer attached firmly to the underlying laminae [L3] as a sub-laminae layer of the spore wall (SLW). L3: Inner layer as laminae of the spore wall (LSW), which is continuous with the innermost layer of the subtending hypha. The subtending hypha $(\mathrm{SH})$ is cylindrical to slightly flared with three layers that are continuous with the three layers of the spore wall. The plug partitions the spore from the hyphal contents (septum, S). A septum (S) occludes the hyphal attachment of a thin-walled spore of the pale morph close to the spore base. F. mosseae: Figures 1E,F Crushed spore showing the wall structure as three layers. L1, Outer wall, hyaline, mucilaginous, forming a sloughing granular layer (SSW). L2, Hyaline, generally rigid, consisting of a thin adherent sublayer attached firmly to the underlying laminae (L3). L3, Inner layer consisting of laminae with minute depressions covering the surface and separating L1 and L2. The sporocarp (SC) is subglobose, light brown, and surrounded by a peridium (P). Developed intact spores (IS) were observed. The subtending hypha is funnel-shaped with a width ranging between 16 and $32 \mu \mathrm{m}$ (Figure 1F). As shown in Figure 1E, the subtending hypha consists of two layers (L1, L3), with the sum of thickness ranging between 2.4 and $4.8 \mu \mathrm{m}$. A germ tube emerges from the lumen (funnel-shaped) of the subtending hypha, originating from the occlusion-recovered septum. Sporocarps dramatically produce numerous infective hyphae (Figure 1E). The spores in the current isolates from soil adhering to the roots of $A$. gerrardii were identified as $F$. mosseae (syn. Glomus mosseae), R. intraradices (syn. Glomus intraradices), and C. etunicatum (syn. Glomus etunicatum).

\section{Plant Growth Parameters}

The germination of $A$. gerrardii seeds was tested at $\mathrm{NaCl}$ concentrations of 50-300 mM. The results showed that increases in salt concentration decreased the germination rate of the seeds compared to that of the control seeds (water only) (from 87 to $3 \%$ ). Because germination of the seeds was strongly impaired by $300 \mathrm{mM} \mathrm{NaCl}$, we used $250 \mathrm{mM} \mathrm{NaCl}$ in all further salt stress experiments.

The growth of $A$. gerrardii was strongly impaired by salinity when plants were not inoculated with AMF or endophytic bacteria. Salinity reduced shoot height and shoot dry weight by 61 and $62 \%$, respectively, and root length and dry weight were reduced by 35 and 38\%, respectively (Table 1), compared with non-stressed plants. Salt-stressed shoots were 35\% shorter and root depth $61 \%$ less in plants treated with $250 \mathrm{mM} \mathrm{NaCl}$ than non-stressed plant shoots and roots. 


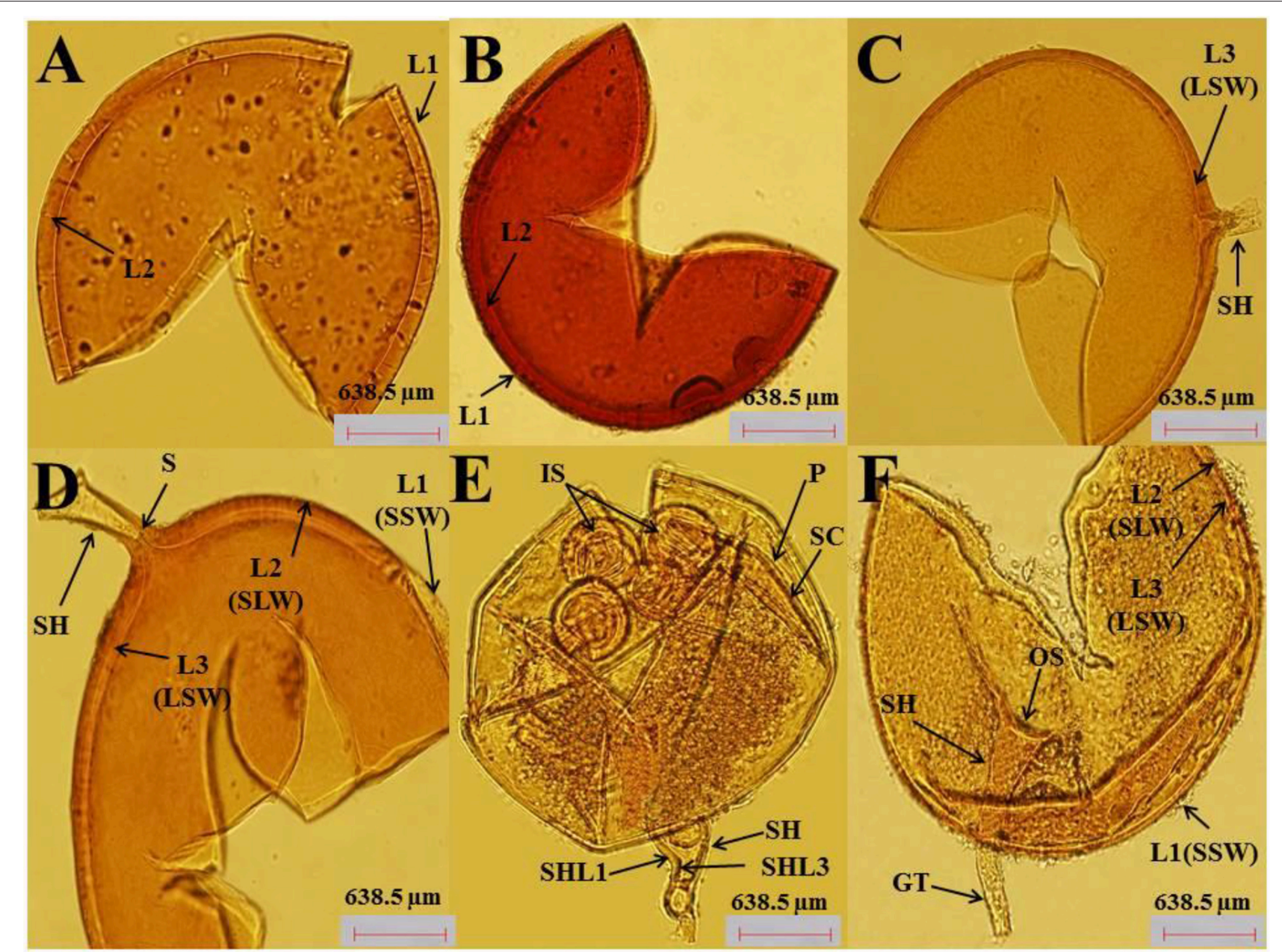

FIGURE 1 | (A-F) (40X). AMF spores were isolated from soil samples of $A$. gerrardii. (A,B) The microscopic investigation indicated that the crushed spores of $C$. etunicatum were globose, sub-globose in shape, orange to red-brown in color and consisted of two layers (L1 and L2).. (C,D) Describes the spore morphology of R. intraradices as globose to subglobose in shape and whose crushed spores consisted of three layers (L1, L2, and L3) and prominent subtending hyphae. (E,F) The microscopic investigation revealed that the spores of $F$. mosseae are clustered together within a compact peridium. The shape of the spores was globose to subglobose, and the spore wall consisted of three layers ( $L 1, \mathrm{~L} 2$, and $\mathrm{L} 3)$.

TABLE 1 | Shoot and root growth of Acacia gerrardii under salt stress after inoculation with B. subtilis and AMF alone and in combination.

\begin{tabular}{|c|c|c|c|c|c|c|c|}
\hline \multicolumn{2}{|c|}{ Treatments } & \multirow{2}{*}{$\begin{array}{c}\text { SH (cm) } \\
53.4 \pm 1.7\end{array}$} & \multirow{2}{*}{$\begin{array}{l}\text { SDW }(\mathbf{g}) \\
1.94 \pm 0.2\end{array}$} & \multirow{2}{*}{$\begin{array}{c}\mathbf{R D}(\mathbf{c m}) \\
70.9 \pm 2.1\end{array}$} & \multirow{2}{*}{$\begin{array}{c}\text { RDW (g) } \\
2.78 \pm 0.3\end{array}$} & \multirow{2}{*}{$\begin{array}{c}\text { SH/RD } \\
0.75 \pm 0.04\end{array}$} & \multirow{2}{*}{$\begin{array}{l}\text { SDW/RDW } \\
0.70 \pm 0.03\end{array}$} \\
\hline $0 \mathrm{mM} \mathrm{NaCl}$ & Control & & & & & & \\
\hline & BS & $78.4 \pm 1.9$ & $2.95 \pm 0.3$ & $87.0 \pm 2.4$ & $3.66 \pm 0.4$ & $0.90 \pm 0.05$ & $0.80 \pm 0.04$ \\
\hline & $\mathrm{BS}+\mathrm{AMF}$ & $80.2 \pm 2.1$ & $3.55 \pm 0.4$ & $92.1 \pm 3.1$ & $3.87 \pm 0.4$ & $0.87 \pm 0.06$ & $0.91 \pm 0.05$ \\
\hline \multirow[t]{4}{*}{$250 \mathrm{mM} \mathrm{NaCl}$} & Control & $20.8 \pm 1.0$ & $0.74 \pm 0.1$ & $46.0 \pm 1.2$ & $1.72 \pm 0.1$ & $0.45 \pm 0.02$ & $0.43 \pm 0.01$ \\
\hline & AMF & $29.1 \pm 1.2$ & $1.13 \pm 0.1$ & $56.8 \pm 1.3$ & $2.09 \pm 0.2$ & $0.51 \pm 0.03$ & $0.54 \pm 0.03$ \\
\hline & $\mathrm{BS}+\mathrm{AMF}$ & $48.1 \pm 1.3$ & $1.82 \pm 0.2$ & $66.4 \pm 1.4$ & $2.63 \pm 0.1$ & $0.72 \pm 0.04$ & $0.69 \pm 0.04$ \\
\hline & LSD $p<0.05:$ & 2.80 & 0.08 & 1.31 & 0.12 & 0.04 & 0.04 \\
\hline
\end{tabular}

SH, shoot height; SDW, shoot dry weight; RD, root depth; RDW, root dry weight; \pm , standard deviation. 
Plant growth depended strongly on the presence or absence of both AMF and the endophytic bacterium, BS. The inoculation of plants with $B$. subtilis alone or with AMF enhanced the root and shoot growth of non-stressed A. gerrardii, and the difference between the uninoculated and co-inoculated plants was significant (Table 1). Roots inoculated with the endophytic BS alone were significantly longer (22\%) than uninoculated roots and were longer (14\%) than roots inoculated with AMF alone (Table 1). In general, plant growth responded positively to the BS inoculation compared to AMF alone.

Salt-stressed A. gerrardii inoculated with endophytic B. subtilis alone grew better than salt-treated uninoculated plants. Root dry weight increased by $40 \%$ and shoot dry weight by $118 \%$ in the presence of $250 \mathrm{mM} \mathrm{NaCl}$ (Table 1). Shoot height and root length also responded positively to a single inoculation of BS. Root and shoot growth varied between treatments with the single inoculants and were higher in plants inoculated with the endophytic BS strain than with AMF. However, the interaction of AMF and rhizobia affected plant productivity positively compared to a single inoculation. Co-inoculated A. gerrardii had significantly higher shoot and root weight than plants inoculated with AMF or BS alone under $\mathrm{NaCl}$ stress (Table 1, Figure S1).

\section{Colonization of AMF in Plant Roots}

The colonization of fine $A$. gerrardii roots by AMF is shown in Figures 2A-F. The roots were colonized with different AMF morphological structures, such as vesicles (Figure 2A), spores (Figure 2C), mycelium hyphae, intraradical hyphae (Figure 2B), subtending hyphae (Figure 2C), coiled hyphae (Figure 2E), and arbuscules (Figure 2F).

The percentage of $67.6,55.8$, and 13.8 of AMF that colonized the roots of $A$. gerrardii were in the form of mycelia, vesicles and arbuscules, respectively, with a total spore density of 707.8 spores/g of experimental soil (Table S1). $\mathrm{NaCl}$ stress decreased spore density, the presence of mycelia, vesicles and arbuscules by $24.8,63.6,20.7$, and $60.4 \%$, respectively, compared with the control treatment. Endophytic BS alleviated the adverse impacts of salt on spore density and mycorrhizal fungal colonization, and total spore count, mycelium, vesicles and arbuscules were increased by $27,96,14$, and $23 \%$, respectively, compared with those in the salt stress treatment group. In the absence of salt stress, the endophytic BS significantly increased both spore intensity and mycelium by 78.6 and $29.5 \%$, respectively. However, both vesicles and arbuscules decreased by 48.38 and $44.92 \%$, respectively, compared to those of the control treatment.

\section{Number of Nodules, Nodule Fresh Weight, and Leghemoglobin Content}

The number of nodules, nodule FW and leghemoglobin content were reduced by $80.8,80.04$, and $80.6 \%$, respectively, in saltstressed plants relative to control, unstressed plants (Table 2). A. gerrardii grown in AMF-infected soil showed a higher number of nodules, nodule FW and leghemoglobin content (25.9, 51.8, and $18.02 \%$, respectively) than plants grown in control soil in both non-saline and saline conditions. The root nodulation of
A. gerrardii depended strongly on the presence or absence of AMF and/or the endophytic bacterium, B. subtilis (Table 2). BS and AMF alone improved the symbiotic performance of saltstressed A. gerrardii. However, plants co-inoculated with AMF and $B$. subtilis produced three times more nodules, nodule FW, and leghemoglobin content in $250 \mathrm{mM} \mathrm{NaCl}$ than those in uninoculated plants.

\section{Nitrate Reductase, Nitrite Reductase, Nitrogenase, and Crude Protein}

Both AMF and endophytic BS applied alone to non-stressed and stressed plants increased the nitrate (NR) and nitrite reductase (NIR) as well as nitrogenase activity. Inoculation of AMF increased nitrate reductase, nitrite reductase and nitrogenase activity by $15.4,10.1$, and $20.7 \%$, respectively, while BS enhanced the activity of these enzymes by $31.5,32.2$, and $40.06 \%$, respectively (Table 2 ).

The combined inoculation of AMF and BS increased nitrate reductase, nitrite reductase, and nitrogenase activity in the nodules of $A$. gerrardii by $42.5,43.7$, and $48.2 \%$, respectively (Table 2), while salt-stressed plants showed a 38.5, 46.4, and $72.8 \%$ decline in nitrate reductase, nitrite reductase, and nitrogenase activity, respectively. The differences in enzyme activities between uninoculated plants and those co-inoculated with $\mathrm{AMF}$ and BS under salt stress were significant, and nitrate reductase activity increased by $56 \%$, nitrite reductase activity by $53 \%$ and nitrogenase activity by $189 \%$ (Table 2 ). The crude protein content increased in response to all microbial inoculation treatments regardless of whether salt was present. The combination of BS and AMF produced even better results because co-inoculated salt-stressed plant nodules contained significantly more protein than uninoculated salt-stressed ones (Table 2).

Table 3 show the correlations between salt, mycorrhiza, and bacteria with number of nodules, nodule FW, leghemoglobin nodule FW, nitrate reductase, nitrite reductase, nitrogenase, total nitrogen content, and crude protein. The results indicated a slight correlation between mycorrhiza and nitrite reductase (0.185). However, there was a strong correlation between the number of nodules and nitrate reductase (0.996).

\section{Photosynthetic Pigments}

The photosynthetic pigments [chlorophyll $a$ (ChlA), chlorophyll $b$ (ChlB)], carotenoids and total chlorophyll (TChl) content in A. gerrardii were lower in plants without microbial inoculants or with only one inoculant. When plants were grown in the presence of AMF or BS, photosynthetic pigments increased, ChlA by 19.4 or $30.3 \%$, ChlB by 12.6 or $28.3 \%$, carotenoids by 41.8 or $62.5 \%$ and total chlorophyll content by 15.4 or $32.5 \%$, respectively, compared to uninoculated plants (Table S2). Salinity reduced the content of $\mathrm{ChlA}, \mathrm{ChlB}$, carotenoids and TChl in A. gerrardii by $32.9,40.5,93.01$, and $41.1 \%$, respectively. Plants inoculated with endophytic BS and grown in soil infested with AMF showed an increase in the content of photosynthetic pigments. The content of ChlA, ChlB, carotenoids and TChl varied between the single inoculant treatments and was higher in plants inoculated with the endophytic BS strain than in those 

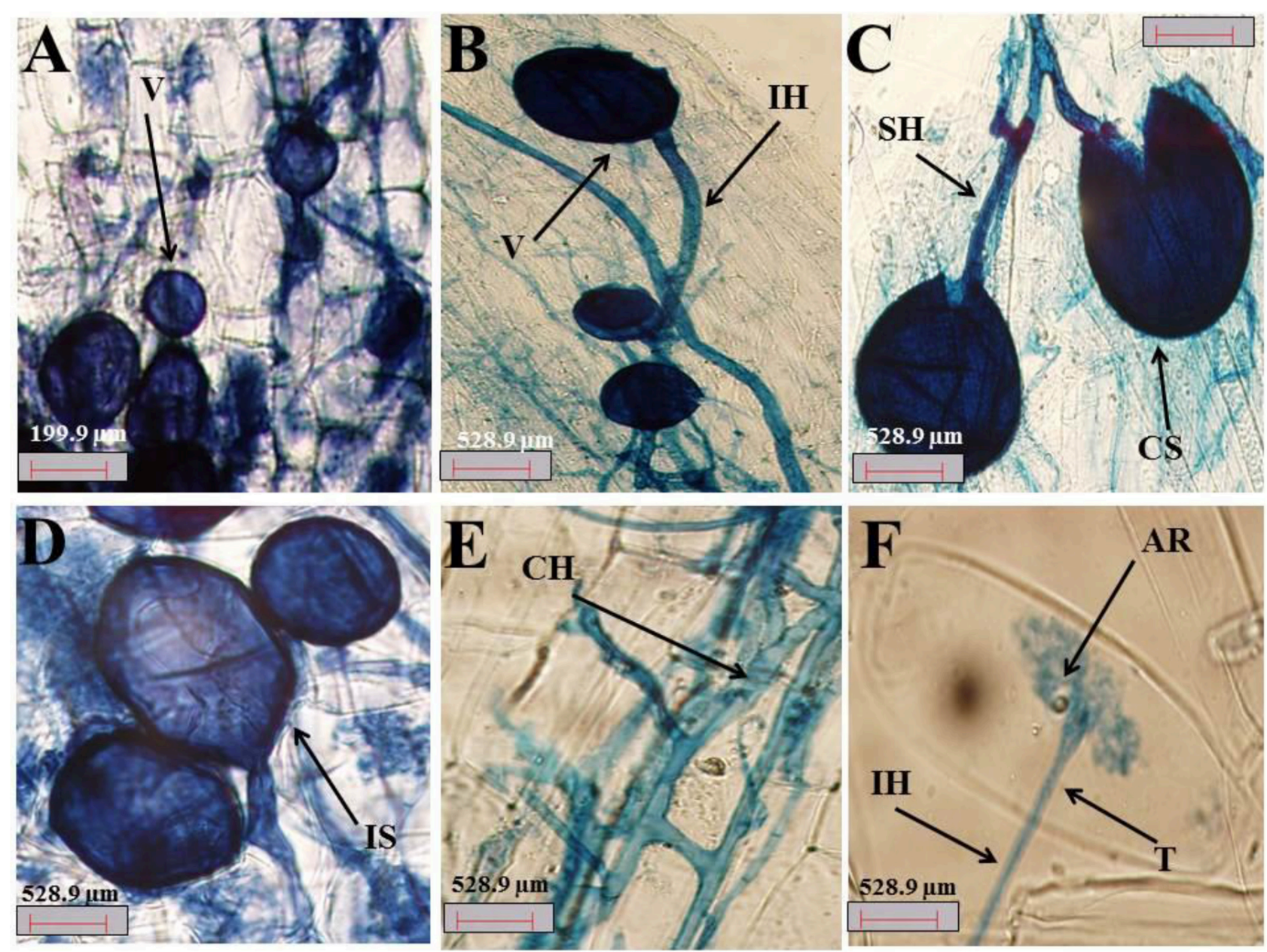

FIGURE 2 | (A-F) Photomicrographs of structural colonization of AMF in the roots of $A$. gerrardii. (A) Vesicles (V); (B) intraradical hypha (IH), and vesicles (V). (C) crushed spore (CS) and subtending hypha (SH). (D) Intact spore (IS). (E) Coiled hyphae (CH). (F) Arbuscule (AR), trunk (T) and Intraradical hypha (IH).

TABLE 2 | Nodule number, fresh weight, leghemoglobin content, nitrate and nitrite reductase, and nitrogenase activity of Acacia gerrardii nodules under salt stress after inoculation with $B$. subtilis and AMF alone and in combination.

\begin{tabular}{|c|c|c|c|c|c|c|c|c|}
\hline \multicolumn{2}{|c|}{ Treatments } & \multirow{2}{*}{$\begin{array}{c}\text { NN } \\
57.1 \pm 1.8\end{array}$} & \multirow{2}{*}{$\begin{array}{c}\text { NFW } \\
1.2 \pm 0.04\end{array}$} & \multirow{2}{*}{$\begin{array}{c}\mathbf{L G} \\
6.2 \pm 0.5\end{array}$} & \multirow{2}{*}{$\begin{array}{c}\text { NR } \\
8.5 \pm 0.7\end{array}$} & \multirow{2}{*}{$\begin{array}{c}\mathbf{N i R} \\
6.1 \pm 0.5\end{array}$} & \multirow{2}{*}{$\begin{array}{c}\mathbf{N G} \\
125.3 \pm 10.3\end{array}$} & \multirow{2}{*}{$\begin{array}{c}\text { CP } \\
593.1 \pm 43.7\end{array}$} \\
\hline 0 mM NaCl & Control & & & & & & & \\
\hline & BS & $92.9 \pm 2.3$ & $2.1 \pm 0.07$ & $8.9 \pm 0.7$ & $11.1 \pm 0.9$ & $8.1 \pm 0.7$ & $175.5 \pm 12.6$ & $887.9 \pm 62.1$ \\
\hline & AMF & $71.9 \pm 1.9$ & $1.8 \pm 0.05$ & $7.4 \pm 0.7$ & $9.8 \pm 0.8$ & $6.7 \pm 0.5$ & $151.3 \pm 11.2$ & $729.7 \pm 51.7$ \\
\hline & $\mathrm{BS}+\mathrm{AMF}$ & $106.4 \pm 2.7$ & $2.4 \pm 0.09$ & $9.1 \pm 0.8$ & $12.1 \pm 1.2$ & $8.8 \pm 0.8$ & $185.7 \pm 13.4$ & $997.5 \pm 83.6$ \\
\hline \multirow[t]{5}{*}{$250 \mathrm{mM} \mathrm{NaCl}$} & Control & $10.9 \pm 0.4$ & $0.2 \pm 0.01$ & $1.2 \pm 0.1$ & $5.2 \pm 0.3$ & $3.2 \pm 0.2$ & $34.0 \pm 3.1$ & $163.8 \pm 13.7$ \\
\hline & BS & $45.9 \pm 1.2$ & $0.9 \pm 0.02$ & $4.7 \pm 0.2$ & $7.8 \pm 0.5$ & $4.3 \pm 0.3$ & $90.2 \pm 8.4$ & $493.5 \pm 32.4$ \\
\hline & AMF & $31.4 \pm 0.7$ & $0.7 \pm 0.01$ & $3.1 \pm 0.1$ & $6.3 \pm 0.4$ & $4.1 \pm 0.3$ & $75.7 \pm 6.4$ & $408.1 \pm 27.5$ \\
\hline & $\mathrm{BS}+\mathrm{AMF}$ & $50.6 \pm 1.6$ & $1.0 \pm 0.03$ & $4.9 \pm 0.3$ & $8.1 \pm 0.7$ & $5.0 \pm 0.4$ & $98.7 \pm 8.6$ & $550.9 \pm 37.8$ \\
\hline & $\operatorname{LSD} p<0.05$ & 2.75 & 0.07 & 0.44 & 0.19 & 0.59 & 2.00 & 14.97 \\
\hline
\end{tabular}

$N N$, number of nodules; LG, leghemoglobin (mg g ${ }^{-1}$ nodule FW); NR, nitrate reductase ( $\mu m \mathrm{NO}_{2}$ released/h/g FW), NiR, nitrite reductase ( $\mu \mathrm{m} N \mathrm{O}_{2}$ disappeared/h/g FW); NG, nitrogenase ( mole ethylene/mg nodule FW/h); CP, crude protein (total nitrogen content as mg/g dry weight $\times 6.25$ ); \pm , standard deviation.

inoculated with AMF (Table S2). A weak correlation was found between mycorrhiza and carotenoids (0.203), while the strongest correlation (0.998) was between chlorophyll $a+$ chlorophyll $b$ and total photosynthetic pigments followed by the correlation between chlorophyll $a$ and total photosynthetic pigments (0.992; Table S3). 
TABLE 3 | Correlations (r) between salt, mycorrhiza, and bacteria with number of nodules, nodule fresh weight, leghemoglobin nodule fresh weight, nitrate reductase, nitrite reductase, nitrogenase, total nitrogen content, and crude protein.

\begin{tabular}{|c|c|c|c|c|c|c|c|c|c|c|c|}
\hline & Sal & M & B & NN & NFW & LG & NR & $\mathrm{NiR}$ & NG & TN & CP \\
\hline Sal & 1.00000 & 0.00000 & 0.00000 & -0.80434 & -0.82441 & -0.84506 & -0.80299 & -0.84272 & -0.86851 & -0.79585 & -0.79585 \\
\hline M & & 1.00000 & 0.00000 & 0.22748 & 0.27535 & 0.16619 & 0.21210 & 0.18576 & 0.22121 & 0.27398 & 0.27398 \\
\hline B & & & 1.00000 & 0.52874 & 0.45420 & 0.45913 & 0.54203 & 0.38903 & 0.41955 & 0.51745 & 0.51745 \\
\hline NN & & & & 1.00000 & 0.98822 & 0.97559 & 0.99642 & 0.94935 & 0.98308 & 0.99350 & 0.99350 \\
\hline NFW & & & & & 1.00000 & 0.96027 & 0.98864 & 0.93981 & 0.98060 & 0.98396 & 0.98396 \\
\hline LG & & & & & & 1.00000 & 0.97490 & 0.96162 & 0.98319 & 0.97358 & 0.97358 \\
\hline NR & & & & & & & 1.00000 & 0.94095 & 0.98127 & 0.98920 & 0.98920 \\
\hline $\mathrm{NiR}$ & & & & & & & & 1.00000 & 0.94270 & 0.93546 & 0.93546 \\
\hline$N G$ & & & & & & & & & 1.00000 & 0.98790 & 0.98790 \\
\hline TN & & & & & & & & & & 1.00000 & 1.00000 \\
\hline $\mathrm{CP}$ & & & & & & & & & & & 1.00000 \\
\hline
\end{tabular}

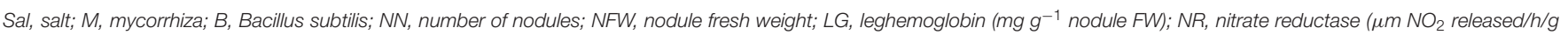

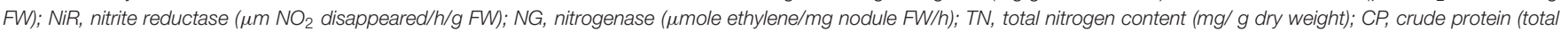
nitrogen content as $\mathrm{mg} / \mathrm{g}$ dry weight $\times 6.25$ ).

\section{Nutrient Contents}

The nutrient contents decreased following treatment with 250 $\mathrm{mM} \mathrm{NaCl}, \mathrm{N}$ content by $72 \%$ and $\mathrm{P}$ by $59 \%, \mathrm{~K}$ by $53 \%$, Mg by $65 \%$, and $\mathrm{Ca}$ by $60 \%$ (Table 4 ). $\mathrm{NaCl}$ stress increased $\mathrm{Na}^{+}$and $\mathrm{Cl}^{-}$content compared to plants under non-stressed conditions. Generally, both inoculation treatments, either BS alone or combined with AMF, enhanced $\mathrm{Na}^{+}, \mathrm{P}, \mathrm{K}^{+}, \mathrm{Mg}^{2+}$, and $\mathrm{Ca}^{2+}$ contents in non-stressed and salt-stressed A. gerrardii tissues (Table 4). However, the highest concentrations were detected in co-inoculated plant tissues grown in the presence of $250 \mathrm{mM} \mathrm{NaCl}$. The correlations between salt, mycorrhiza, and bacteria with sodium, potassium, magnesium, calcium and chloride contents are shown in Table 5. The strongest correlation was between calcium and potassium (0.935), while the weakest correlation was between mycorrhiza and potassium (0.211).

\section{Acid and Alkaline Phosphatases}

Acid phosphatase (AP) activity significantly increased as a consequence of salinity in uninoculated plant tissues (Figure 3). The acid and ALP increased by 78.3 and $116.9 \%$, respectively, in response to $250 \mathrm{mM} \mathrm{NaCl}$ compared to non-stressed control plants. Inoculation with AMF had a stimulatory effect on the activity of both phosphatases in non-stressed and stressed plants (Figures 3A,B). Following combined inoculation of AMF and BS, AP activity increased by 142.7 and $147.3 \%$ in $250 \mathrm{mM} \mathrm{NaCl}$ and in unstressed control plants, respectively.

\section{DISCUSSION}

The results from our experiments showed that a tripartite interaction of AMF, endophytic BS and the host plant $A$. gerrardii may have the potential to remediate degraded sites and can compensate for abiotic stresses due to climate change. Although, several reports have shown a positive effect of dual inoculation with AMF and PGPR on plant growth and stress tolerance, such as AMF with Enterobacter radicincitans on faba bean (Vicia faba)
(Almethyeb et al., 2013), AMF with Pseudomonas mendocina on lettuce (Lactuca sativa L.) (Kohler et al., 2009), AMF with Pseudomonas fluorescens on common bean (Phaseolis vulgaris L.) (Neeraj and Singh, 2011), and AMF with Azospirillum on rice (Oryza sativa. L) (Ruíz-Sánchez et al., 2011), little is known about the interactions with endophytes as well as the underlying mechanisms. In this study, we observed a significant growth benefit of the synergistic association of A. gerrardii with AMF and endophytic $B$. subtilis under salt stress.

We found that salt stress reduced AMF colonization in $A$. gerrardii, consistent with observations made by Alqarawi et al. (2014a) in Ephedra aphylla and Hashem et al. (2015) in Vigna unguiculata. Our results showed that combined inoculation of plants with AMF and endophytic B. subtilis resulted in increased AMF colonization, which is an important indicator of plant nutrition. The synergistic interaction of $B$. subtilis and AMF altered $A$. gerrardii plant fitness under salt stress, significantly increasing plant biomass, nodulation, leghemoglobin, and crude protein content compared with untreated plants. An increase in plant growth and amelioration of salt stress by AMF was reported by Abd_Allah et al. (2015a) for sunflower (Helianthus annuus L.), by Aroca et al. (2013) for lettuce, and by GomezBellot et al. (2015) for laurustinus plants (Viburnum tinus L.). Bacterial endophytes have also been shown to increase plant growth and tolerance to abiotic stresses, e.g., P. fluorescens (Ali et al., 2014), Paenibacillus yonginensis (Sukweenadhi et al., 2015), and Bacillus sp. (Andreolli et al., 2016). When colonizing plant tissues, microbes contribute multiple benefits, such as improved nutrient acquisition, tolerance to biotic and abiotic stresses, and modulation of plant defenses (Bordiec et al., 2011). In addition, the increase in nodulation may be due to a synergistic effect of the two types of microbes, namely symbiotic and endophytic, including naturally occurring rhizobia. Huang et al. (2011) reported a mutualistic symbiotic relationship between B. subtilis and a leguminous plant, Robinia pseudoacacia L. In this study, B. subtilis colonized plant roots in a manner 
TABLE 4 | Mineral contents of Acacia gerrardii under salt stress after inoculation with B. subtilis and AMF alone and in combination.

\begin{tabular}{|c|c|c|c|c|c|c|c|c|}
\hline \multicolumn{2}{|c|}{ Treatments } & \multicolumn{7}{|c|}{ Accumulation of elements (mg/g dry weight) } \\
\hline & $\mathrm{Na}$ & $\mathbf{K}$ & Mg & $\mathbf{C a}$ & $\mathbf{C l}$ & $\mathbf{N}$ & $\mathbf{P}$ & \\
\hline \multirow[t]{4}{*}{$0 \mathrm{mM} \mathrm{NaCl}$} & Control & $11.3 \pm 0.9$ & $28.3 \pm 2.5$ & $2.1 \pm 0.2$ & $2.8 \pm 0.2$ & $8.1 \pm 0.6$ & $94.8 \pm 8.2$ & $1.6 \pm 0.1$ \\
\hline & BS & $15.7 \pm 1.2$ & $32.9 \pm 3.1$ & $3.5 \pm 0.3$ & $4.0 \pm 0.3$ & $5.2 \pm 0.3$ & $142.0 \pm 12.4$ & $1.8 \pm 0.1$ \\
\hline & AMF & $12.4 \pm 1.1$ & $29.6 \pm 2.7$ & $2.2 \pm 0.2$ & $3.6 \pm 0.3$ & $7.0 \pm 0.5$ & $116.7 \pm 10.3$ & $2.9 \pm 0.2$ \\
\hline & $\mathrm{BS}+\mathrm{AMF}$ & $17.0 \pm 1.4$ & $35.1 \pm 3.2$ & $2.8 \pm 0.2$ & $4.6 \pm 0.4$ & $4.6 \pm 0.2$ & $159.6 \pm 13.5$ & $3.2 \pm 0.2$ \\
\hline \multirow[t]{5}{*}{$250 \mathrm{mM} \mathrm{NaCl}$} & Control & $37.3 \pm 3.1$ & $13.3 \pm 1.1$ & $0.7 \pm 0.04$ & $1.1 \pm 0.06$ & $27.2 \pm 1.9$ & $26.2 \pm 2.3$ & $0.6 \pm 0.04$ \\
\hline & BS & $26.2 \pm 2.4$ & $23.5 \pm 2.1$ & $1.6 \pm 0.1$ & $2.2 \pm 0.2$ & $13.7 \pm 1.1$ & $78.9 \pm 6.4$ & $1.0 \pm 0.07$ \\
\hline & AMF & $28.8 \pm 2.5$ & $18.3 \pm 1.6$ & $1.0 \pm 0.08$ & $2.0 \pm 0.2$ & $19.4 \pm 1.7$ & $65.3 \pm 6.1$ & $1.2 \pm 0.1$ \\
\hline & $\mathrm{BS}+\mathrm{AMF}$ & $25.0 \pm 2.3$ & $26.6 \pm 2.4$ & $1.8 \pm 0.1$ & $2.4 \pm 0.2$ & $11.0 \pm 0.8$ & $88.1 \pm 7.6$ & $1.4 \pm 0.1$ \\
\hline & LSD $p<0.05$ & 1.51 & 0.54 & 0.11 & 0.25 & 0.28 & 2.14 & 0.16 \\
\hline
\end{tabular}

Na, sodium; K, potassium; Mg, magnesium; Ca, calcium; N, nitrogen; P, phosphorous; \pm , standard deviation.

TABLE 5 | Correlations (r) between salt, mycorrhiza, and bacteria with sodium, potassium, magnesium, calcium, and chloride.

\begin{tabular}{|c|c|c|c|c|c|c|c|c|}
\hline & Sal & $\mathbf{M}$ & B & $\mathrm{Na}$ & K & Mg & Ca & $\mathrm{Cl}$ \\
\hline Sal & 1.00000 & 0.00000 & 0.00000 & 0.88260 & -0.80382 & -0.79170 & -0.81818 & 0.79031 \\
\hline M & & 1.00000 & 0.00000 & -0.10702 & 0.21197 & -0.02390 & 0.28581 & -0.20716 \\
\hline B & & & 1.00000 & -0.08547 & 0.51986 & 0.54310 & 0.42853 & -0.46092 \\
\hline $\mathrm{Na}$ & & & & 1.00000 & -0.85107 & -0.75276 & -0.77220 & 0.90348 \\
\hline $\mathrm{K}$ & & & & & 1.00000 & 0.91692 & 0.93540 & -0.97884 \\
\hline $\mathrm{Mg}$ & & & & & & 1.00000 & 0.90114 & -0.88184 \\
\hline $\mathrm{Ca}$ & & & & & & & 1.00000 & -0.88885 \\
\hline $\mathrm{Cl}$ & & & & & & & & 1.00000 \\
\hline
\end{tabular}

Sal, salt; M, mycorrhiza; B, Bacillus subtilis; Na, sodium; K, potassium; Mg, magnesium; Ca, calcium; Cl, chloride.

similar to the infection of root hairs by rhizobia and formed bacteroids inside plant cortical cells. Inoculation of plants with cellulose-producing B. subtilis resulted in more nodules and higher nitrogenase activity than the uninoculated control and AMF-inoculated plants. Rhizobial symbionts penetrate deeper plant tissues by producing cellulase, which can completely erode the root-hair wall at the site of infection (Sindhu and Dadarwal, 2001). The synthesis of cell wall-degrading enzymes by B. subtilis could help explain the mechanism underlying rhizobial entry into target root hair cells to form nodules.

Increased nitrogenase activity following treatments with $B$. subtilis or B. subtilis combined with AMF resulted from their positive impact on the activity of enzymes such as nitrate reductase and nitrite reductase. Nitrate and nitrite reductase control the conversion of nitrate into ammonia and result in the formation of amino acids (Iqbal et al., 2015). In Trifolium alexandrinum L. and Trifolium resupinatum L. (Zarea et al., 2011), as well as in Vicia faba (Hashem et al., 2014), inoculation of AMF enhanced plant growth by improving nitrogenase activity and nodule formation.

High salt concentrations induce alterations in the synthesis of chlorophyll-related proteins and components of the oxygenevolving complex, resulting in reduced photosynthetic efficiency (Alqarawi et al., 2014a,b). Altered de novo synthesis of proteins and the associated pigment-related components due to salinity has negative effects on the synthesis of photoassimilates and hence reduces the growth rate of plants. The combined inoculation of AMF and B. subtilis increase photosynthetic pigments, which may be a collective result of many positive changes induced by AMF and PGPR. The enhanced chlorophyll content due to AMF inoculation under normal as well as NaClstressed conditions corroborates the reports of Aroca et al. (2013) in lettuce, Alqarawi et al. (2014a) in E. aphylla and Abd_Allah et al. (2015a) in Sesbania sesban. Recently, in saltstressed Brassica juncea, Ahmad et al. (2015) demonstrated the positive impact of Trichoderma harzianum inoculation on growth via improved chlorophyll synthesis. In Ocimum basilicum grown under water stress, inoculation of PGPR (Pseudomonas sp. and Bacillus lentus) increased chlorophyll synthesis as well photosynthetic electron transport and also mitigated the negative impact of water stress (Heidari and Golpayegani, 2012).

Salt stress inhibits the uptake of essential mineral elements, such as $\mathrm{K}, \mathrm{Mg}, \mathrm{Ca}, \mathrm{N}$, and $\mathrm{P}$, because of the antagonistic relationship of sodium. By reducing the uptake of magnesium, salt stress affects plant photosynthetic efficiency by altering the synthesis of chlorophyll molecules. Reduced uptake of nitrogen directly affects the nitrogen metabolic potential as well as amino acid synthesis in plants (Näsholm et al., 2009). Improved plant nutrient uptake under salt stress conditions by AMF was reported in many studies e.g., for common bean (Phaseolus vulgaris) 

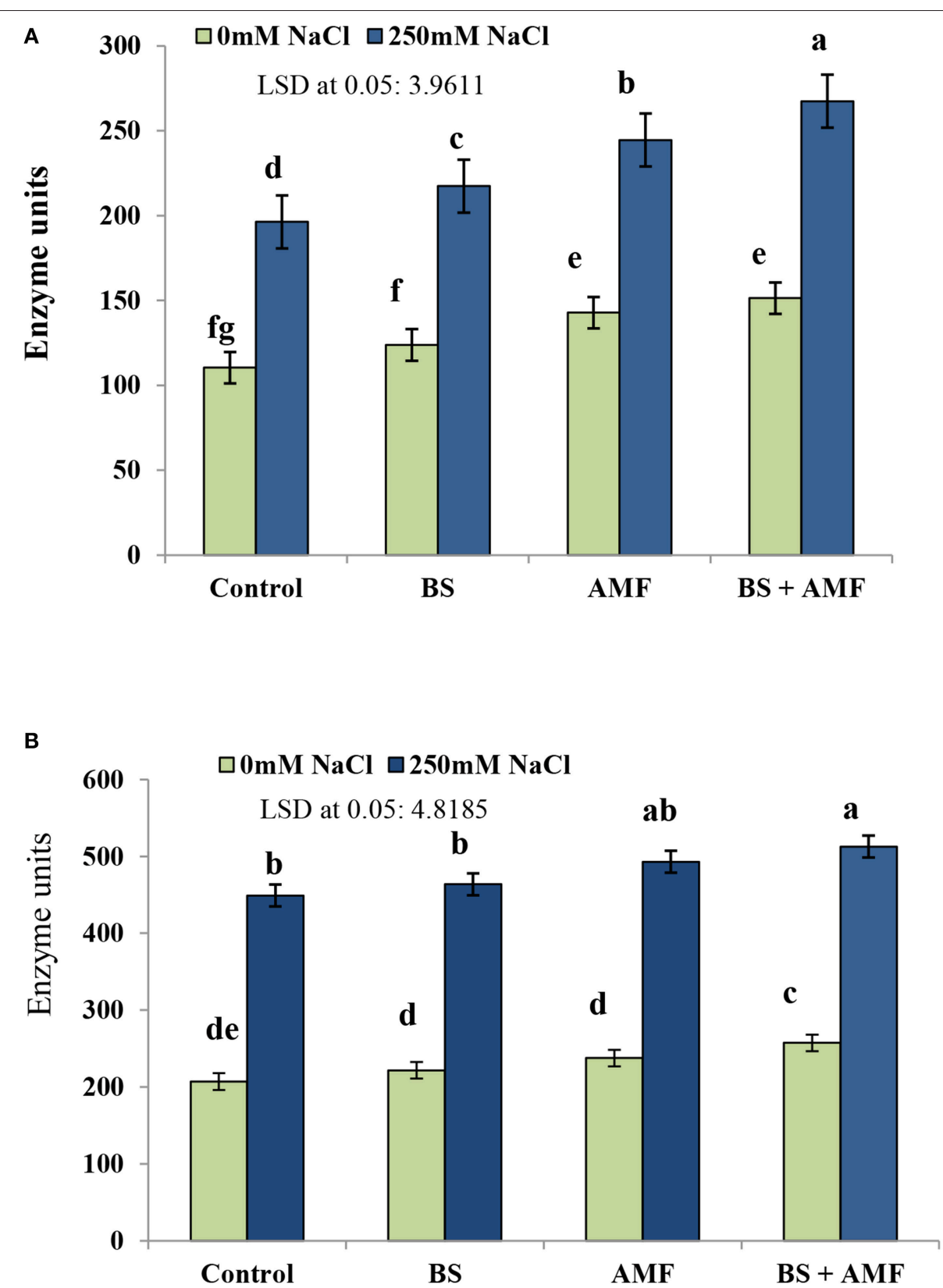

FIGURE 3 | The enzymes activity (Unit) of acid phosphatase (A) and alkaline phosphatase (B) in fresh root of Acacia gerrardii in response to endophytic $\boldsymbol{B}$. subtilis under salt stress $(250 \mathbf{~ m M ~ N a C l})$. Columns represent means for five plants $(N=5)$. Error bars show standard error. Columns with different letters indicate significant differences between treatments at $P<0.05$.

(Abd_Allah et al., 2015b), olive (Olea europaea L.) (PorrasSoriano et al., 2009), and wheat (Triticum aestivum L.) (Talaat and Shawky, 2014). Endophytic bacterial strains can also increase plant tolerance to abiotic stresses and improve nutrient uptake under multiple adverse conditions (Malfanova et al., 2011; Berg et al., 2013). The combined inoculation of plants with AMF and PGPR reduced the $\mathrm{Na}$ and $\mathrm{Cl}$ concentrations in plant tissues, thereby protecting salt-stressed plants from ionic and osmotic stress-induced changes. Their synergistic interaction resulted in an increase of N, P, and K uptake by plants. Endophytic bacterial strains appear to have some plant growth-promoting activities, such as IAA production and solubilization of phosphate, which together or alone might explain the capacity of B. subtilis to improve plant growth and nutrient acquisition (Malfanova et al., 2011). Messele and Pant (2012) observed improved nodulation, yield and $\mathrm{P}$ uptake in chickpea (Cicer arietinum) by phosphatesolubilizing Pseudomonas. An increase in P availability to plants through the action of phosphate-solubilizing bacteria (PSB) has also been reported for green gram (Vigna radiata $\mathrm{L}$. Wilczek) (Vikram and Hamzehzarghani, 2008) and wheat (T. aestivum 
L.) (Panhwar et al., 2011). In earlier studies, it was reported that salt and drought stresses inhibit the production of plant growth regulators in plant tissues (Debez et al., 2001). The additional supply of hormones by endophytes in plant tissue can stimulate the root system, thereby facilitating the absorption of more nutrients from the soil, especially under stress conditions (Malfanova et al., 2011; Berg et al., 2013). Studies by Kavino et al. (2010), Heidari et al. (2011), and Lavakush et al. (2014) also support the positive impact of PGPR on the mineral nutrient status of plants under normal and stressed conditions in determining the physiological strength of a plant. Improved $\mathrm{Mg}$ content affects chlorophyll, while $\mathrm{P}$ and $\mathrm{N}$ contribute to the energy budget of a cell, and Ca serves as an important cellular messenger for downstream signaling (Ahanger et al., 2014b). Improved $\mathrm{K}$ uptake is associated with reduced $\mathrm{Na}$ uptake in AMF- and PGPR-inoculated plants and results in an enhanced $\mathrm{K} / \mathrm{Na}$ ratio, an important aspect for the maintenance of physiological cellular functioning (Abd_Allah et al., 2015a,b; Ahanger et al., 2015).

Phosphatases are responsible for the hydrolysis of a range of organic $\mathrm{P}$ compounds and provide mineral phosphate to the plant (Tazisong et al., 2015). In our study, increased acid and ALP was observed in A. gerrardii grown under salt stress. Similarly, enhanced AP activity under salt stress was also observed in Medicago sativa (Ehsanpour and Amini, 2003) and may be due to the fact that salt stress suppresses plant growth, P uptake, transport and utilization (Dracup et al., 1984). An increase in the activities of phosphatases (alkaline and acidic phosphatase) following the combined inoculation of $A$. gerrardii plants with $\mathrm{AMF}$ and $B$. subtilis support the findings of Amaya-Carpio et al. (2009) in Ipomoea carnea sp. fistulosa and Kebrabadi et al. (2014) in Fraxinus rotundifolia. During $\mathrm{P}$ deficiency or impaired $\mathrm{P}$ uptake, plants release or activate acid phosphates and exude carboxylates and phosphatases to enhance P solubilization and uptake (Veneklaas et al., 2003). An increase in the activity of phosphatases in inoculated plants, either with AMF or B. subtilis, alone or in combination, can contribute to the release of bound $\mathrm{P}$ to maximize its

\section{REFERENCES}

Abd_Allah, E. F., Hashem, A., Alqarawi, A. A., and Alwhibi, M. S. (2015b). Alleviation of adverse impact of salt in Phaseolus vulgaris 1 . by arbuscular mycorrhizal fungi. Pak. J. Bot. 47, 1167-1176.

Abd_Allah, E. F., Hashem, A., Alqarawi, A. A., Bahkali, A. H., and Alwhibi, M. S. (2015a). Enhancing growth performance and systemic acquired resistance of medicinal plant Sesbania sesban (L.) Merr using arbuscular mycorrhizal fungi under salt stress. Saudi J. Bio. Sci. 22, 274-283.

Abd_Allah, E. F., Hashem, A., Alqarawi, A. A., and Hend, A. (2015c). Alleviation of adverse impact of cadmium stress in sunflower (Helianthus annuus 1.) by arbuscular mycorrhizal fungi. Pak. J. Bot. 47, 785-795.

Ahanger, M. A., Agarwal, R. M., Tomar, N. S., and Shrivastava,. M. (2015). Potassium induces positive changes in nitrogen metabolism and antioxidant system of oat (Avena sativa L cultivar Kent). J. Plant Int. 10, 211-223. doi: 10.1080/17429145.2015.1056260

Ahanger, M. A., Hashem, A., Abd_Allah, E. F., and Ahmad, P. (2014a). “Arbuscular mycorrhiza in crop improvement under environmental stress," in Emerging Technologies and Management of Crop Stress Tolerance, Vol. 2, eds P. Ahmad and S. Rasool (San Diego, CA: Academic Press; Elsevier), 69-95. uptake and transport. Maize plants inoculated with B. subtilis showed an increase in phosphatase activity compared to uninoculated controls (Hussain et al., 2013). Salinity-stressed plants showed lower $\mathrm{P}$ accumulation in the above-ground plant parts, which may be due to the toxicity of high salt concentrations.

\section{CONCLUSION}

Our observations in this study indicate that endophytic bacteria and AMF that live within the plant tissues of $A$. gerrardii are coordinately involved in the plant's adaptation to stress tolerance. Inoculation of plants with AMF and endophytic B. subtilis increased plant growth and nutrient acquisition and improved symbiotic performance of $A$. gerrardii. In addition, endophytic $B$. subtilis increased AMF germination and root colonization of $A$. gerrardii under salt stress.

\section{AUTHOR CONTRIBUTIONS}

AAH, Provided the seeds and seedlings. AH, Provided AMF and mycological analysis. EA, All biochemical analysis, writing and graphing. AAA, Statistical analysis. SW, Revision and editing. DE, writing, revision and editing.

\section{ACKNOWLEDGMENTS}

The authors would like to extend their sincere appreciation to the Deanship of Scientific Research at King Saud University for its funding of this research through the Research Group Project no RGP-271.

\section{SUPPLEMENTARY MATERIAL}

The Supplementary Material for this article can be found online at: http://journal.frontiersin.org/article/10.3389/fmicb. 2016.01089

Ahanger, M. A., Tyagi, S. R., Wani, M. R., and Ahmad, P. (2014b). "Drought tolerance: role of organic osmolytes, growth regulators, and mineral nutrients," in Physiological Mechanisms and Adaptation Strategies in Plants Under Changing Environment, eds P. Ahmad and M. R. Wani (New York, NY: Springer; Science+Business Media), 25-55.

Ahmad, P. (2010). Growth and antioxidant responses in mustard (Brassica juncea L.) plants subjected to combined effect of gibberellic acid and salinity. Arch. Agro. Soil Sci. 56, 575-588. doi: 10.1080/03650340903164231

Ahmad, P., Hashem, A., Abd-Allah, E. F., Alqarawi, A. A., John, R., Egamberdieva, D., et al. (2015). Role of Trichoderma harzianum in mitigating $\mathrm{NaCl}$ stress in Indian mustard (Brassica juncea L) through antioxidative defense system. Front. Plant Sci. 6:868. doi:10.3389/fpls.2015.00868

Ali, S., Charles, T. C., and Glick, B. R. (2014). Amelioration of high salinity stress damage by plant growth-promoting bacterial endophytes that contain ACC deaminase. Plant Physiol. Biochem. 80, 160-167. doi: 10.1016/j.plaphy.2014.04.003

Allen, M. B. (1953). Experiments in Soil Bacteriology, 1st Edn. Minneapolis: Burgess Pub. Co.

Almethyeb, M., Ruppel, S., Paulsen, H. M., Vassilev, N., and Eichler-Löbermann, B. (2013). Single and combined applications of arbuscular mycorrhizal fungi and 
Enterobacter radicincitans affect nutrient uptake of faba bean and soil biological characteristics. Agric. Fores. Res. 3, 229-234. doi: 10.3220/LBF_2013_229-234

Alqarawi, A. A., Abd_Allah, E. F., and Hashem, A. (2014a). Alleviation of saltinduced adverse impact via mycorrhizal fungi in Ephedra aphylla Forssk. J. Plant Inter. 9, 802-810. doi: 10.1080/17429145.2014.949886

Alqarawi, A. A., Abd_Allah, E. F., Hashem, A., Al-Huqail, A. A., and Al-Sahli, A. A. (2014b). Impact of abiotic salt stress on some metabolic activities of Ephedra alata Decne. J. Food Agr. Environ. 12, 620-625.

Amaya-Carpio, L., Davies, F. T., Fox, T., and He, C. (2009). Arbuscular mycorrhizal fungi and organic fertilizer influence photosynthesis, root phosphatase activity, nutrition, and growth of Ipomoea carnea ssp. fistulosa. Photosynthetica 47, 1-10. doi: 10.1007/s11099-009-0003-x

Andreolli, M., Lampis, S., Zapparoli, G., Angelini, E., and Vallini, G. (2016). Diversity of bacterial endophytes in 3 and 15 year-old grapevines of Vitis vinifera cv. Corvina and their potential for plant growth promotion and phytopathogen control. Microb. Res. 183, 42-52. doi: 10.1016/j.micres.2015.11.009

AOAC (Association of Official Analytical Chemists) (1995). Official Methods of Analysis of AOAC International, 16th Edn., Vol. 2. Arlington, VA: AOAC International.

Ardakani, M. R., Pietsch, G., Moghaddam, A., Raza, A., and Friedel, J. K. (2009). Response of root properties to tripartite symbiosis between lucerne (Medicago sativa L.), rhizobia and mycorrhiza under dry organic farming conditions. Am. J. Agric. Biol. Sci. 4, 266-277. doi: 10.3844/ajabssp.2009.266.277

Arnon, D. I. (1949). Copper enzymes in isolated chloroplasts. polyphenoloxidase in Beta vulgaris. Plant Physiol. 24, 1-15. doi: 10.1104/pp.24.1.1

Aroca, R., Ruiz-Lozano, J. M., Zamarreno, A., Paz, J. A., Garcia-Mina, J. M., Pozo, M. J., et al. (2013). Arbuscular mycorrhizal symbiosis influences strigolactone production under salinity and alleviates salt stress in lettuce plants. J. Plant Physiol. 170, 47-55. doi: 10.1016/j.jplph.2012.08.020

Bano, N., and Musarrat, J. (2003). Characterization of a new Pseudomonas aeruginosa strain NJ-15 as a potential biocontrol agent. Curr. Microb. 46, 324-328. doi: 10.1007/s00284-002-3857-8

Barnawal, D., Bharti, N., Maji, D., Chanotiya, C. S., and Kalra, A. (2014). ACC deaminase-containing Arthrobacter protophormiae induces $\mathrm{NaCl}$ stress tolerance through reduced ACC oxidase activity and ethylene production resulting in improved nodulation and mycorrhization in Pisum sativum. J. Plant Physiol. 171, 884-894. doi: 10.1016/j.jplph.2014.03.007

Berg, G., Alavi, M., Schmidt, C. S., Zachow, C., Egamberdieva, D., Kamilova, F., et al. (2013). "Biocontrol and osmoprotection for plants under saline conditions," in Molecular Microbial Ecology of the Rhizosphere, ed F. J. De Bruijn (Hoboken, NJ: Wiley-Blackwell)

Bethlenfalvay, G. J., and Yoder, J. F. (1981). The Glycine-Glomus-Rhizobium symbiosis. I. Phosphorus effect on nitrogen fixation and mycorrhizal infection. Physiol. Plant. 52, 141-145. doi: 10.1111/j.1399-3054.1981.tb06047.x

Bordiec, S., Paquis, S., Lacroix, H., Dhondt, S., Ait Barka, E., Kauffmann, S., et al. (2011). Comparative analysis of defence responses induced by the endophytic plant growth-promoting rhizobacterium Burkholderia phytofirmans strain PsjN and the non-host bacterium Pseudomonas syringae pv. pisi in grapevine cell suspensions. J. Exp. Bot. 62, 595-603. doi: 10.1093/jxb/erq291

Bouhmouch, I., Souad-Mouhsine, B., Brhada, F., and Aurag, J. (2005). Influence of host cultivars and Rhizobium species on the growth and symbiotic performance of Phaseolus vulgaris under salt stress. J. Plant Physiol. 162, 1103-1113. doi: 10.1016/j.jplph.2004.12.003

Daniels, B. A., and Skipper, H. D. (1982). "Methods for the recovery and quantitative estimation of propagules from soil," in Methods and Principles of Mycorrhizal Research, ed N. C. Schenck (St. Paul Minnesota: American Phytopathological Society), 29-36.

Debez, A., Chaibi, W., and Bouzid, S. (2001). Effect du $\mathrm{NaCl}$ et de regulatoeurs de croissance sur la germination d'Atriplex halimus L. Cahiers Agric. 10, 135-138.

Dracup, M. N. H., Barrett-Lennard, E. G., Greenway, H., and Robson, A. D. (1984). Effect of phosphorus deficiency on phosphatase activity of cell walls from roots of subterranean clover. J. Exp. Bot. 35, 466-480. doi: 10.1093/jxb/35. 4.466

Egamberdieva, D. (2012). Pseudomonas chlororaphis: a salt tolerant bacterial inoculant for plant growth stimulation under saline soil conditions. Acta Physiol. Plant. 34, 751-756. doi: 10.1007/s11738-011-0875-9
Egamberdieva, D., Berg, G., Lindström, K., and Räsänen, L. A. (2013). Alleviation of salt stress of symbiotic Galega officinalis L. (goat's rue) by co-inoculation of rhizobium with root colonising Pseudomonas. Plant Soil 369, 453-465. doi: 10.1007/s11104-013-1586-3

Egamberdieva, D., Jabborova, D., and Berg, G. (2015). Synergistic interactions between Bradyrhizobium japonicum and the endophyte Stenotrophomonas rhizophila and their effects on growth, nodulation and nutrition of soybean under salt stress. Plant Soil 1-11.

Egamberdieva, D., Li, L., Lindström, K., and Räsänen, L. (2016). A synergistic interaction between salt tolerant Pseudomonas and Mezorhizobium strains improves growth and symbiotic performance of liquorice (Glycyrrhiza uralensis Fish.) under salt stress. Appl. Microb. Biotechnol. 100, 2829-2841. doi: 10.1007/s00253-015-7147-3

Ehsanpour, A. A., and Amini, F. (2003). Effect of salt and drought stress on acid phosphatase activites in alfalfa (Medicago sativa L.) explants under in vitro culture. Afr. J. Biotech. 2, 133-135. doi: 10.5897/AJB2003.000-1026

Finka, R. L., Warner, R. L., and Muzit, T. J. (1977). Effect of herbicides on in vivo nitrate and nitrite reduction. Weed Sci. 25, 18-22.

Gerdemann, J. W., and Nicolson, T. H. (1963). Spores of mycorrhizal Endogone extracted from soil by wet sieving and decanting. Trans. Brit. Mycol. Soc. 46, 235-244. doi: 10.1016/S0007-1536(63)80079-0

Gianinazzi-Pearson, V., and Gianinazzi, S. (1976). Enzymatic studies on the metabolism of vesicular-arbuscular mycorrhiza. I. Effect of mycorrhiza formation and phosphorus nutrition on soluble phosphatase activities in onion roots. Physiol. Veg. 14, 833-841.

Gomez-Bellot, M. J., Nortes, P. A., Ortuno, M. F., Romero, C., Fernandez-García, C., and Sanchez-Blanco, M. J. (2015). Influence of arbuscular mycorrhizal fungi and treated wastewater onwater relations and leaf structure alterations of Viburnum tinus L. plants during both saline and recovery periods. J. Plant Physiol. 188, 96-105. doi: 10.1016/j.jplph.2015.09.007

Gupta, P., Samant, K., and Sahu, A. (2012). Isolation of cellulose-degrading bacteria and determination of their cellulolytic potential. Int. J. Microbiol. 2012:578925. doi: 10.1155/2012/578925

Hageman, R. H., and Hucklesby, D. P. (1971). "Nitrate reductase from higher plants," in Methods in Enzymology, ed A. S. Pietro (New York, NY: Academic Press), 491-503.

Hashem, A., Abd_Allah, E. F., Alqarawi, A. A., Al-Didamony, G., Al-Whibi, M., Egamberdieva, D., et al. (2014). Alleviation of adverse impact of salinity on faba bean (Vicia faba L.) by arbuscular mycorrhizal fungi. Pak. J. Bot. 46, 2003-2013.

Hashem, A., Abd_Allah, E. F., Alqarawi, A. A., and Egamberdieva, D. (2015). Induction of salt stress tolerance in cowpea (Vigna unguiculata L. Walp) by arbuscular mycorrhizal fungi. Legume Res. 38, 579-588. doi: 10.18805/lr.v38i5.5933

Heidari, M., and Golpayegani, A. (2012). Effects of water stress and inoculation with plant growth promoting rhizobacteria (PGPR) on antioxidant status and photosynthetic pigments in basil (Ocimum basilicum L.). J. Saudi Society Agri. Sci. 11, 57-61. doi: 10.1016/j.jssas.2011.09.001

Heidari, M., Mousavinik, S. M., and Golpayegani, A. (2011). Plant growth promoting rhizobacteria (PGPR) effect on physiological parameters and mineral uptake in basil (Ociumum basilicum L.) under water stress. J. Agri. Bio. Sci. 6, 6-11.

Huang, B., Lv, C., Zhuang, P., Zhang, H., and Fan, L. (2011). Endophytic colonisation of Bacillus subtilis in the roots of Robinia pseudoacacia L. Plant Biol. 13, 925-931. doi: 10.1111/j.1438-8677.2011.00456.x

Hussain, M. I., Asghar, H. N., Akhtar, M. J., and Arshad, M. (2013). Impact of phosphate solubilizing bacteria on growth and yield of maize. Soil Environ. 32, 71-78.

Ikawa, I. J., Nisizawa, K., and Mira, N. K. (1964). Specifications of several acid phosphatases from plant sources. Nature 203, 939-940. doi: 10.1038/203939a0

Iqbal, N., Umar, S., and Khan, N. A. (2015). Nitrogen availability regulates proline and ethylene production and alleviates salinity stress in mustard (Brassica juncea). J. Plant Physiol. 178, 84-91. doi: 10.1016/j.jplph.2015.0 2.006

Jackson, M. L. (1962). Soil Chemical Analysis. New York, NY: Prentice Hall.

Kavino, M., Harish, S., Kumar, N., Saravanakumar, D., and Samiyappan, R. (2010). Effect of chitinolytic PGPR on growth, yield and physiological attributes of 
banana (Musa spp.) under field conditions. Appl. Soil Ecol. 45, 71-77. doi: 10.1016/j.apsoil.2010.02.003

Kebrabadi, B. Z., Matinizadeh, M., Daryayi, M. G., and Salehi, A. (2014). Changes in acid and alkaline phosphatase enzyme activity in rhizosphere ash Fraxinus rotundifolia and its correlation with soil and plant phosphorus. J. Biod. Env. Sci. 4, 233-238.

Keilin, D., and Wang, Y. L. (1945). Hemoglobin in the root nodules of leguminous plants. Nature 155, 227-229. doi: 10.1038/155227a0

Kohler, J., Hernandez, J. A., Caravaca, F., and Roldan, A. (2009). Induction of antioxidant enzymes is involved in the greater effectiveness of a PGPR versus AM fungi with respect to increasing the tolerance of lettuce to severe salt stress. Environ. Exp. Bot. 65, 245-252. doi: 10.1016/j.envexpbot.2008. 09.008

Kormanik, P. P., and McGraw, A. C. (1982). "Quantification of vesiculararbuscular mycorrhizal in plant roots," in Methods and Principles of Mycorrhizal Research, ed N. C. Schenck (St. Paul, MN: American Phytopatholgy Society), 37-46.

Lavakush, Y. J., Verma, J. P., Jaiswal, D. K., and Kumar, A. (2014). Evaluation of PGPR and different concentration of phosphorus level on plant growth, yield and nutrient content of rice (Oryza sativa). Ecol. Engin. 62, 123-128. doi: 10.1016/j.ecoleng.2013.10.013

Ligero, F., Lluch, C., and Olivares, J. (1986). Evolution of ethylene from roots of Medicago sativa plants inoculated with Rhizobium meliloti. J. Plant Physiol. 125, 361-365. doi: 10.1016/S0176-1617(86)80158-4

Malfanova, N., Kamilova, F., Validov, S., Shcherbakov, A., Chebotar, V., Tikhonovich, I., et al. (2011). Characterization of Bacillus subtilis HC8, a novel plant-beneficial endophytic strain from giant hogweed. Microb. Biotech. 4, 523-532. doi: 10.1111/j.1751-7915.2011.00253.x

Marschner, P., Yang, C. H., Lieberei, R., and Crowley, D. E. (2001). Soil and plant specific effects on bacterial community composition in the rhizosphere. Soil Biol. Biochem. 33, 1437-1445. doi: 10.1016/S0038-0717(01)00052-9

Messele, B., and Pant, L. M. (2012). Effects of Inoculation of Sinorhizobium ciceri and phosphate solubilizing bacteria on nodulation, yield and nitrogen and phosphorus uptake of chickpea (Cicer arietinum L.) in Shoa Robit Area. J. Biofertil. Biopest. 3:129. doi: 10.4172/2155-6202.10000129

Mohanta, M. K., Saha, A. K., Saleh, D. K. M. A., Islam, M. S., Mannan, K. S. B., and Fakruddin, M. (2015). Characterization of Klebsiella granulomatis pathogenic to silkworm, Bombyx mori L. 3 Biotech. 5, 577-583. doi: 10.1007/s13205-0140255-4

Muyzer, G., Teske, A., Wirsen, C. O., and Jannasch, H. W. (1995). Phylogenetic relationships of Thiomicrospira species and their identification in deep-sea hydrothermal vent samples by denaturing gradient gel electrophoresis of $16 \mathrm{~S}$ rDNA fragments. Arch. Microb. 164, 165-171. doi: 10.1007/BF02529967

Nadeem, S. M., Ahmadm, M., Zahir, Z. A., Javaid, A., and Ashraf, M. (2014). The role of mycorrhizae and plant growth promoting rhizobacteria (PGPR) in improving crop productivity under stressful environments. Biotech. Adv. 32, 429-448. doi: 10.1016/j.biotechadv.2013.12.005

Näsholm, T., Kielland, K., and Ganeteg, U. (2009). Uptake of organic nitrogen by plants. New Phytol. 182, 31-48. doi: 10.1111/j.1469-8137.2008.02751.x

Navarro, J. M., Perez-Tornero, O., and Morte, A. (2013). Alleviation of salt stress in citrus seedlings inoculated with arbuscular mycorrhizal fungi depends on the rootstock salt tolerance. J. Plant Physiol. 171, 76-85. doi: 10.1016/j.jplph.2013.06.006

Neeraj and Singh, K. (2011). Organic amendments to soil inoculated arbuscular mycorrhizal fungi and Pseudomonas fluorescens treatments reduce the development of root-rot disease and enhance the yield of Phaseolus vulgaris L. Eur. J. Soil Biol. 47, 288-295. doi: 10.1016/j.ejsobi.2011.07.002

Panhwar, Q. A., Radziah, O., Khanif, Y. M., and Naher, U. A. (2011). Application of boron and zinc in the tropical soils and its effect on maize (Zea mays L.) growth and soil microbial environment. Aust. J. Crop Sci. 5, 1649-1654.

Phillips, J. M., and Hayman, D. S. (1970). Improved procedures for clearing and staining parasitic and vesicular-arbuacular mycorrhizal fungi for rapid assessment of infection. Trans. Br. Mycol. Soc. 55, 158-161. doi: 10.1016/S00071536(70)80110-3

Pikovskaya, R. I. (1948). Mobilization of phosphorus in soil connection with the vital activity of some microbial species. Microbiologiya 17, 362-370.

Porcel, R., Aroca, R., and Ruiz-Lozano, J. M. (2012). Salinity stress alleviation using arbuscular mycorrhizal fungi. A review. Agron. Sust. Dev. 32, 181-200. doi: 10.1007/s13593-011-0029-x
Porras-Soriano, A., Sorano-Marintin, M. L., Porras-Piedra, A., and Azcon, P. (2009). Arbuscular mycorrhizal fungi increased growth, nutrient uptake and tolerance to salinity in olive trees under nursery conditions. J. Plant Physiol. 166, 1350-1359. doi: 10.1016/j.jplph.2009.02.010

Redecker, D., Schüßler, A., Stockinger, H., Stürmer, S. L., Morton, J. B., and Walker, C. (2013). An evidence-based consensus for the classification of arbuscular mycorrhizal fungi (Glomeromycota). Mycorrhiza 23, 515-531. doi: 10.1007/s00572-013-0486-y

Ruiz-Lozano, J. M., Porcel, R., Azcon, R., and Aroca, R. (2012). Regulation by arbuscular mycorrhizae of the integrated physiological response to salinity in plants. New challenges in physiological and molecular studies. J. Exp. Bot. 63, 4033-4044. doi: 10.1093/jxb/ers126

Ruíz-Sánchez, M., Armada, E., Munoz, Y., de Salamone, I. E. G., Aroca, R., Ruíz-Lozano, J. M., et al. (2011). Azospirillum and arbuscular mycorrhizal colonization enhance rice growth and physiological traits under wellwatered and drought conditions. J. Plant Physiol. 168, 1031-1037. doi: 10.1016/j.jplph.2010.12.019

Schüßler, A., and Walker, C. (2010). The Glomeromycota: A Species List with New Families and Genera. Gloucester.

Sessitsch, A., Hardoim, P., Döring, J., Weilharter, A., Krause, A., Woyke, T., et al. (2012). Functional characteristics of an endophyte community colonizing rice roots as revealed by metagenomic analysis. Mol. Plant Microbe Interact. 25, 28-36. doi: 10.1094/MPMI-08-11-0204

Sheng, M., Tang, M., Chan, H., Yang, B., Zhang, F., and Huang, Y. (2008). Influence of arbuscular mycorrhizae on photosynthesis and water status of maize plants under salt stress. Mycorrhiza 18, 287-296. doi: 10.1007/s00572008-0180-7

Silsbury, J. H. H. (1990). Growth nitrogen accumulation and partitioning, and $\mathrm{N}_{2}$ fixation in faba bean (Vicia faba cv. Fiord) and pea (Pisum sativum cv. Early Dun). Field Crops Res. 24, 173-188. doi: 10.1016/0378-4290(90) 90036-B

Sindhu, S. S., and Dadarwal, K. R. (2001). Chitinolytic and cellulolytic Pseudomonas sp. antagonistic to fungal pathogens enhances nodulation by Mesorhizobium sp. cicer in chickpea. Microbiol. Res. 156, 353-358. doi: 10.1078/0944-5013-00120

Slattery, J. F., Conventry, D. R., and Slattery, W. J. (2001). Rhizobial ecology as affected by the soil environment. Aust. J. Exp. Agric. 41, 289-298. doi: 10.1071/EA99159

Stutz, J. C., and Morton, J. B. (1996). Successive pot cultures reveal high species richness of arbuscular mycorrhizal fungi in arid ecosystems. Can. J. Bot. 74, 1883-1889. doi: 10.1139/b96-225

Sukweenadhi, J., Kima, Y. J., Choi, E., Koh, S. C., Lee, S. W., Kim, Y. J., et al. (2015). Paenibacillus yonginensis DCY84T induces changes in Arabidopsis thaliana gene expression against aluminum, drought, and salt stress. Microb. Res. 172, 7-15. doi: 10.1016/j.micres.2015.01.007

Tajini, F., Trabelsi, M., and Drevona, J. J. (2012). Combined inoculation with Glomus intraradices and Rhizobium tropici CIAT899 increases phosphorus use efficiency for symbiotic nitrogen fixation in common bean (Phaseolus vulgaris L.). Saudi J. Biol. Sci. 19, 157-163. doi: 10.1016/j.sjbs.2011. 11.003

Talaat, N. B., and Shawky, B. T. (2014). Protective effects of arbuscular mycorrhizal fungi on wheat (Triticum aestivum L.) plants exposed to salinity. Environ. Exp. Bot. 98, 20-31. doi: 10.1016/j.envexpbot.2013.10.005

Tazisong, I. A., Senwo, Z. N., and He, Z. (2015). Phosphatase hydrolysis of organic phosphorus compounds. Adv. Enz. Res. 3, 39-51. doi: 10.4236/aer.2015.32005

Töpper, B., Larsen, A., Thingstad, T. F., Thyrhaug, R., and Sandaa, R.-A. (2010). Bacterial community composition in an Arctic phytoplankton mesocosm bloom: the impact of silicate and glucose. Polar Biol. 33, 1557-1565. doi: 10.1007/s00300-010-0846-4

Torriani, A. M. (1967). “Alikaline phosphatase from Escherichia coli," in Procedures in Nucleic Acid Research, eds G. L. Cantoni and D. L. Davies (New York, NY: Harper and Row Publishers, Inc.), 224-235.

Utobo, E. B., Ogbodo, E. N., and Nwogbaga, A. C. (2011). Techniques for extraction and quantification of arbuscular rmycorrhizal fungi. Libyan Agric. Res. Center. Int. 2, 68-78.

Veneklaas, E. J., Stevens, J., Cawthray, G. R., Turner, S., Grigg, A. M., and Lambers, H. (2003). Chickpea and white lupin rhizosphere carboxylates vary with soil properties and enhance phosphorus uptake. Plant Soil 248, 187-197. doi: 10.1023/A:1022367312851 
Vikram, A., and Hamzehzarghani, H. (2008). Effect of phosphate solubilizing bacteria on nodulation and growth parameters of greengram (Vigna radiate L. Wilczek). Res. J. Microbial. 3, 62-72. doi: 10.3923/jm.2008.62.72

Wolf, B. (1982). A comprehensive system of leaf analysis and its use for diagnosing crop nutrient status. Comm. Soil Sci. Plant Anal. 13, 1035-1059. doi: 10.1080/00103628209367332

Wu, Q. S., Ying-Ning, Z., and Abd-Allah, E. F. (2014). "Mycorrhizal Association and ROS in Plants," in Oxidative Damage to Plants, ed P. Ahmad (New York, NY: Academic Press; Elsevier), 453-475.

Xavier, L. J. C., and Germida, J. J. (2002). Response of lentil under controlled conditions to coinoculation with arbuscular mycorrhizal fungi and rhizobia varying in efficacy. Soil Biol Biochem. 34, 181-188. doi: 10.1016/S00380717(01)00165-1

Yinsuo, J., Vincent, M. G., and Colin, J. S. (2004). The Influence of Rhizobium and arbuscular mycorrhizal fungi on nitrogen and phosphorus accumulation by Vicia faba. Ann. Bot. 94, 251-258. doi: 10.1093/aob/mch135
Zarea, M. J., Karimi, N., Goltapeh, E. M., and Ghalavand, A. (2011). Effect of cropping systems and arbuscular mycorrhizal fungi on soil microbial activity and root nodule nitrogenase. J. Saudi Soc. Agri. Sci. 10, 109-120. doi: 10.1016/j.jssas.2011.04.003

Conflict of Interest Statement: The authors declare that the research was conducted in the absence of any commercial or financial relationships that could be construed as a potential conflict of interest.

Copyright (c) 2016 Hashem, Abd_Allah, Alqarawi, Al-Huqail, Wirth and Egamberdieva. This is an open-access article distributed under the terms of the Creative Commons Attribution License (CC BY). The use, distribution or reproduction in other forums is permitted, provided the original author(s) or licensor are credited and that the original publication in this journal is cited, in accordance with accepted academic practice. No use, distribution or reproduction is permitted which does not comply with these terms. 